J. Dairy Sci. 92:2853-2874

doi:10.3168/jds.2008-1920

(c) American Dairy Science Association, 2009.

\title{
Effects of bale moisture and bale diameter on spontaneous heating, dry matter recovery, in vitro true digestibility, and in situ disappearance kinetics of alfalfa-orchardgrass hays ${ }^{1}$
}

\author{
W. K. Coblentz ${ }^{* 2}$ and P. C. Hoffmant \\ *USDA-ARS, US Dairy Forage Research Center, Marshfield, WI 54449 \\ †Department of Dairy Science, University of Wisconsin, Madison 53706
}

\begin{abstract}
Alfalfa (Medicago sativa L.)-orchardgrass (Dactylis glomerata L.) hay was made in 96 large-round bales over 3 harvests during 2006 and 2007 to assess the effects of spontaneous heating on dry matter (DM) recovery, in vitro true digestibility (IVTD), and in situ disappearance kinetics of DM. Throughout these harvests, bales were made at preset diameters of $0.9,1.2$, or 1.5 $\mathrm{m}$ and at moisture concentrations ranging from 9.3 to $46.6 \%$. Internal bale temperatures were monitored daily during an outdoor storage period, reaching maxima of $77.2^{\circ} \mathrm{C}(\mathrm{MAX})$ and 1,997 heating degree days $>30^{\circ} \mathrm{C}$ (HDD) for one specific combination of bale moisture, bale diameter, and harvest. Following storage, regressions of DM recovery on HDD and MAX indicated that DM recovery declined linearly in close association with measures of spontaneous heating. For HDD, slopes and intercepts differed across bale diameters, probably because the greater surface area per kilogram of DM for 0.9-m bales facilitated more rapid dissipation of heat than occurred from 1.2- or 1.5-m-diameter bales. Regardless of bale diameter, coefficients of determination were high $\left(\mathrm{r}^{2} \geq 0.872\right)$ when HDD was used as the independent variable. Regressions of DM recovery on MAX also exhibited high $\mathrm{r}^{2}$ statistics $(\geq 0.833)$ and a common slope across bale diameters $(-0.32$ percentage units of $\left.\mathrm{DM} /{ }^{\circ} \mathrm{C}\right)$. Changes in concentrations of IVTD during storage (poststorage - prestorage; $\triangle \mathrm{IVTD}$ ) also were regressed on HDD and MAX. For HDD, the data were best fit with a nonlinear model in which $\triangle$ IVTD became rapidly negative at $<1,000 \mathrm{HDD}$, but was asymptotic thereafter. When MAX was used as the independent variable, a simple linear model $(\mathrm{y}=$ $-0.23 \mathrm{x}+9.5)$ provided the best fit. In both cases, coef-
\end{abstract}

Received November 21, 2008.

Accepted February 16, 2009.

${ }^{1}$ Mention of trade names or commercial products in this article is solely for the purpose of providing specific information and does not imply either recommendation or endorsement by the US Department of Agriculture.

${ }^{2}$ Corresponding author: wayne.coblentz@ars.usda.gov

ficients of determination were comparable to those for DM recovery $\left(\mathrm{R}^{2}\right.$ or $\left.\mathrm{r}^{2} \geq 0.820\right)$. Changes (poststorage - prestorage) in ruminal DM degradation rate $\left(\Delta K_{d}\right)$ and effective ruminal degradability of DM $(\triangle \mathrm{DEG})$ were assessed similarly. Although the most appropriate statistical model varied, $\Delta \mathrm{K}_{\mathrm{d}}$ and $\triangle \mathrm{DEG}$ both became increasingly negative at low to moderate levels of heating, but generally stabilized thereafter. Both HDD and MAX were excellent predictor variables for both $\Delta \mathrm{K}_{\mathrm{d}}$ and $\triangle \mathrm{DEG} ; \mathrm{r}^{2}$ or $\mathrm{R}^{2}$ statistics ranged from 0.788 to 0.921 . Measures of spontaneous heating are consistently effective indicators of DM recovery following storage, as well as good indicators of concurrent changes in IVTD or in situ disappearance of DM for heated alfalfaorchardgrass hays.

Key words: dry matter loss, hay, spontaneous heating, digestibility

\section{INTRODUCTION}

The harvest, storage, and cash sale of alfalfa and other hays are integral components of dairy and other livestock industries throughout the United States. Currently, producers in the north-central United States who package dairy-quality ( $>151$ relative feed value) alfalfa hay in small rectangular bales can receive approximately $\$ 200 / \mathrm{t}$ for this product. Unfortunately, prevailing weather conditions throughout the region include a relatively high probability of regular rainfall events during considerable portions of the time alfalfa and other hays are growing actively, placing this valuable cash crop at risk. As a result, hay producers in the north-central United States are frequently forced to bale before their hay is desiccated adequately or to subject their wilting hay crop to damage from unpredictable rainfall events.

When hays are too wet at baling, the respiratory activity of microorganisms causes hay to heat spontaneously. Well-known consequences of this phenomenon include oxidation of nonstructural carbohydrates (Coblentz et al., 1997a), mold growth and associated production of toxins (Roberts, 1995), and increased 
concentrations of fiber components and heat-damaged N (Rotz and Muck, 1994). Other studies have related spontaneous heating to losses of DM and a wide range of deleterious changes in forage nutritive value (Collins et al., 1987; Coblentz et al., 1996, 2000; Turner et al., 2002), changes in ruminal disappearance kinetics of $\mathrm{N}$, fiber, and DM (Coblentz et al., 1997b; McBeth et al., 2003; Turner et al., 2004), and less desirable measures of in vitro or in vivo digestibility (Montgomery et al., 1986; Coblentz et al., 2000; McBeth et al., 2001; Turner et al., 2004). Only a few studies (McBeth et al., 2003; Turner et al., 2004) have attempted to relate ruminal in situ disappearance kinetics of DM to spontaneous heating.

It is widely accepted that these undesirable storage characteristics are likely to occur when alfalfa or other hays are baled in small-rectangular packages $(\sim 45$ $\mathrm{kg}$ ) at moisture concentrations $>20 \%$ (Collins et al., 1987). For this bale type, typical measures of forage nutritive value, including fiber fractions and neutralor acid-detergent insoluble $\mathrm{N}$, have been related to measures of spontaneous heating, primarily in linear patterns (Coblentz et al., 1996, 2000) that often exhibit relatively high coefficients of determination $\left(\mathrm{r}^{2}\right)$. However, the cost and availability of labor in recent years have forced many hay or livestock producers to package their hay in large-rectangular or large-round bales. Generally, threshold moisture recommendations for satisfactory storage of these larger hay packages are lower than the $20 \%$ threshold moisture recommended for small-rectangular bales (Collins, 1995), but specific standards often vary with bale type, bale size, storage location, and other factors. Normally, hays baled at $\leq 15 \%$ moisture are assumed to be relatively stable and typically exhibit little evidence of microbial respiration (Rotz and Muck, 1994); however, this has not been investigated thoroughly for larger bale types.

Although all hay experiments are subject to weather conditions that are often unpredictable, small $(45-\mathrm{kg})$ bales have some logistical advantages over larger packages as experimental models because they are relatively easy to replicate and do not require a large land resource to provide adequate bale numbers to evaluate a representative set of treatments. As a result, considerably less information is available concerning storage characteristics, losses of DM, and changes in nutritive value that occur in large hay bales incurring spontaneous heating during storage. The objectives of this study were 2-fold: 1) assess the effects of bale moisture and bale diameter on spontaneous heating within largeround bales of alfalfa-orchardgrass hay during storage; and 2) relate DM recovery, changes in concentrations of whole-plant ash and in vitro true digestibility (IVTD), and characteristics of ruminal in situ DM disappear- ance to measures of spontaneous heating using linear and nonlinear regression techniques.

\section{MATERIALS AND METHODS}

\section{Field Management}

Source of Hays. This project comprised 3 separate harvests conducted on the same 8.2-ha field site over a 2-yr period (2006 and 2007). Soil fertility tests conducted for the field site during the fall of 2006 indicated that $\mathrm{pH}=6.9, \mathrm{P}=114 \mathrm{mg} / \mathrm{kg}, \mathrm{K}=246 \mathrm{mg} / \mathrm{kg}$, and $\mathrm{OM}=3.7 \%$. The forage base at the site consisted of a mixture of 'Phabulous II' alfalfa and 'Extend' orchardgrass and was established on April 14, 2004, near Stratford, Wisconsin $\left(44^{\circ} 7^{\prime} \mathrm{N}, 90^{\circ} 1^{\prime} \mathrm{W}\right)$ on a Loyal silt loam soil (fine-loamy, mixed Oxyaquic Glossoboralfs). In central Wisconsin, it is a common practice of producers to establish minority percentages of perennial grasses (usually orchardgrass) within stands of alfalfa. In practice, this serves as some insurance against winterkill, but also may limit potential for spontaneous heating because grasses typically dry more rapidly and completely than legumes, thereby reducing the moisture concentration at baling relative to monocultures of alfalfa harvested under comparable conditions.

Pretrial Considerations. To meet the objectives of the project, we made several a priori decisions concerning methodology that require explanation. Studies conducted with large hay packages can be complicated logistically and include several obstacles that are not observed when conventional 45-kg hay bales are used as the experimental model. For example, the scope of studies utilizing large-round or large-square bales can be constrained by the available land area, which may limit the number of potential experimental units in each study. For instance, a 3-ha field of alfalfa yielding $2,240 \mathrm{~kg} / \mathrm{ha}$ of hay within a given cutting will provide enough forage for about 150 small rectangular bales weighing approximately $45 \mathrm{~kg}$; in contrast, the same field will provide enough forage for only 15 large-round bales weighing approximately $450 \mathrm{~kg}$. Furthermore, the requirement for larger land areas often injects additional unavoidable confounding into experiments because it increases the likelihood of variability within soil type, topography, hydrology, and the forage base itself. Additionally, small rectangular bales can easily be consolidated into experimental replicates of 4 to 12 stacked bales and stored under a roof for close monitoring during the storage period with relatively little risk of spontaneous combustion. This is not true for large hay packages that require considerably more floor space, are more complicated to evaluate in stacks, and run a much greater chance of combustion during storage. 
An overall goal of this project was to establish a wide continuum of heating characteristics that contained temperature responses from both very dry and very wet hays. However, it was not possible to meet this goal adequately within a single study using an 8.2-ha field site; therefore, it was necessary to combine baling treatments over 3 separate harvests. Rather than spacing baling treatments within each harvest over a range of prestorage bale moistures, we intentionally chose to confine these initial bale moistures within each harvest to relatively narrow ranges, hereafter designated as low(LM; 9.3 to $17.3 \%$ ), intermediate- (IM; 16.8 to $24.2 \%$ ), and high-moisture (HM; 26.7 to $46.6 \%$ ) harvests. This approach provided logistical advantages and increased flexibility with respect to labor schedules, bale management, and processing before storage, and establishment of a suitable range of treatments in spite of sometimes less-than-cooperative weather conditions. Because orchardgrass remains strictly vegetative after the initial hay or silage harvest each spring, only second and third harvests were used in this project, thereby eliminating any potential confounding created by stem elongation.

LM Harvest. Standing forage was mowed at $0900 \mathrm{~h}$ on July 12, 2006, with a Case-International Harvester mower-conditioner (model 8830, J. I. Case Co., Racine, WI) and allowed to wilt until $1000 \mathrm{~h}$ on July 14, when adjacent windrows were raked together with a bi-fold rake. Before raking, the field was divided into 3 field blocks that were based on soil topography (slope); subsequently, these field blocks were retained throughout the IM and HM harvests. For the LM harvest, alfalfa was harvested at first flower, whereas orchardgrass was entirely vegetative following a previous harvest that occurred on June 13, 2006. Before raking, the proportions of alfalfa and orchardgrass in the forage mixture were quantified by walking the entire field in a zigzag pattern, stopping randomly to take grab samples from windrows. This forage was then hand-separated into alfalfa, orchardgrass, and other species, dried to constant weight at $50^{\circ} \mathrm{C}$, and weighed to determine the composition of the sward on a percentage of total dry weight basis (91\% alfalfa and 9\% orchardgrass).

On July 14, hay was baled with a Ford-New Holland round baler (model BR 740A, CNH America, LLC, Racine, WI), and bales were tied with 2 revolutions of net wrap. Treatments were established in a $2 \times 3$ factorial arrangement of moisture concentrations (main effect means $=16.2$ and $11.1 \%$ ) and bale diameters $(1.5,1.2$, and $0.9 \mathrm{~m})$. Bale diameters were selected and produced by utilizing electronic bale monitoring equipment mounted within the cab of the tractor. The 0.9-, $1.2-$, and $1.5-\mathrm{m}$ bale diameters were further maintained across all subsequent harvests, in part to assess the effect of bale diameter on temperature development and
DM recovery, but also to further distribute temperature responses across the widest possible continuum reasonably encountered by producers. Within each field block, bales of the 3 different diameters were created in random order, which was further randomized for each subsequent block. The treatment structure for the LM harvest also contained a very dry control (9.3\% moisture) that was baled at the $1.2-\mathrm{m}$ bale diameter only because of limited forage. Therefore, the LM harvest consisted of 7 treatment combinations of bale moisture and diameter, each replicated in 3 field blocks (21 total bales); all prestorage bale characteristics for these treatment combinations are summarized in Table 1.

IM Harvest. On July 23, 2007, the second cutting at the 8.2-ha field site was mowed at $1000 \mathrm{~h}$ as described previously, following a first cutting that was harvested as silage on June 12. Alfalfa comprised $76 \pm$ $0.9 \%$ of the total forage DM and was harvested at full bloom. Orchardgrass was entirely vegetative regrowth, and comprised $22 \pm 1.3 \%$ of the total forage DM. Hay was raked as described previously at $1000 \mathrm{~h}$ on July 25, and then baled at 4 concentrations of moisture over the remainder of the same day (main effect means $=23.6$, $21.9,18.9$, and $17.1 \%$ ). As described for the LM harvest, bales were packaged at 3 diameters $(0.9,1.2$, and $1.5 \mathrm{~m}$ ) within each moisture concentration. Therefore, the IM harvest consisted of 12 treatment combinations of bale moisture and diameter, each replicated in 3 field blocks (36 total bales); prestorage bale characteristics for these interactive treatment combinations are summarized in Table 1.

HM Harvest. During 2006, the third cutting at the 8.2-ha field site was mowed at $1000 \mathrm{~h}$ on August 28 , and allowed to wilt undisturbed until it was raked at $1000 \mathrm{~h}$ on August 31. On August 29 and 30, the weather conditions were primarily overcast; therefore, wilting proceeded slowly. Beginning at $1315 \mathrm{~h}$ on $\mathrm{Au}-$ gust 31 and continuing through $1630 \mathrm{~h}$ on September 1, hays were baled at 5 concentrations of moisture (main effect means $=45.0,41.6,39.0,31.0$, and $26.7 \%$ ). As described for LM and IM harvests, bales made at 45.0, $41.6,39.0$, and $31.0 \%$ moisture were packaged at 3 diameters $(0.9,1.2$, and $1.5 \mathrm{~m})$. Bales made at $26.7 \%$ moisture were packaged in $0.9-\mathrm{m}$ diameter bales only because of limited forage availability. Therefore, the HM harvest consisted of 13 treatment combinations of bale moisture and diameter, each replicated in 3 field blocks (39 total bales); prestorage bale characteristics for these 13 interactive treatment combinations are summarized in Table 1. At the time of mowing, alfalfa was approaching full bloom and constituted $68 \pm 12.7 \%$ of the stand. Orchardgrass comprised $31 \pm 13.2 \%$ of the stand and was entirely vegetative regrowth at the time of harvest. 
Table 1. Prestorage bale characteristics, heating degree days $>30^{\circ} \mathrm{C}$ (HDD), and maximum internal bale temperatures (MAX) for round bales of alfalfa-orchardgrass hay made at Stratford, Wisconsin, during 2006 and 2007

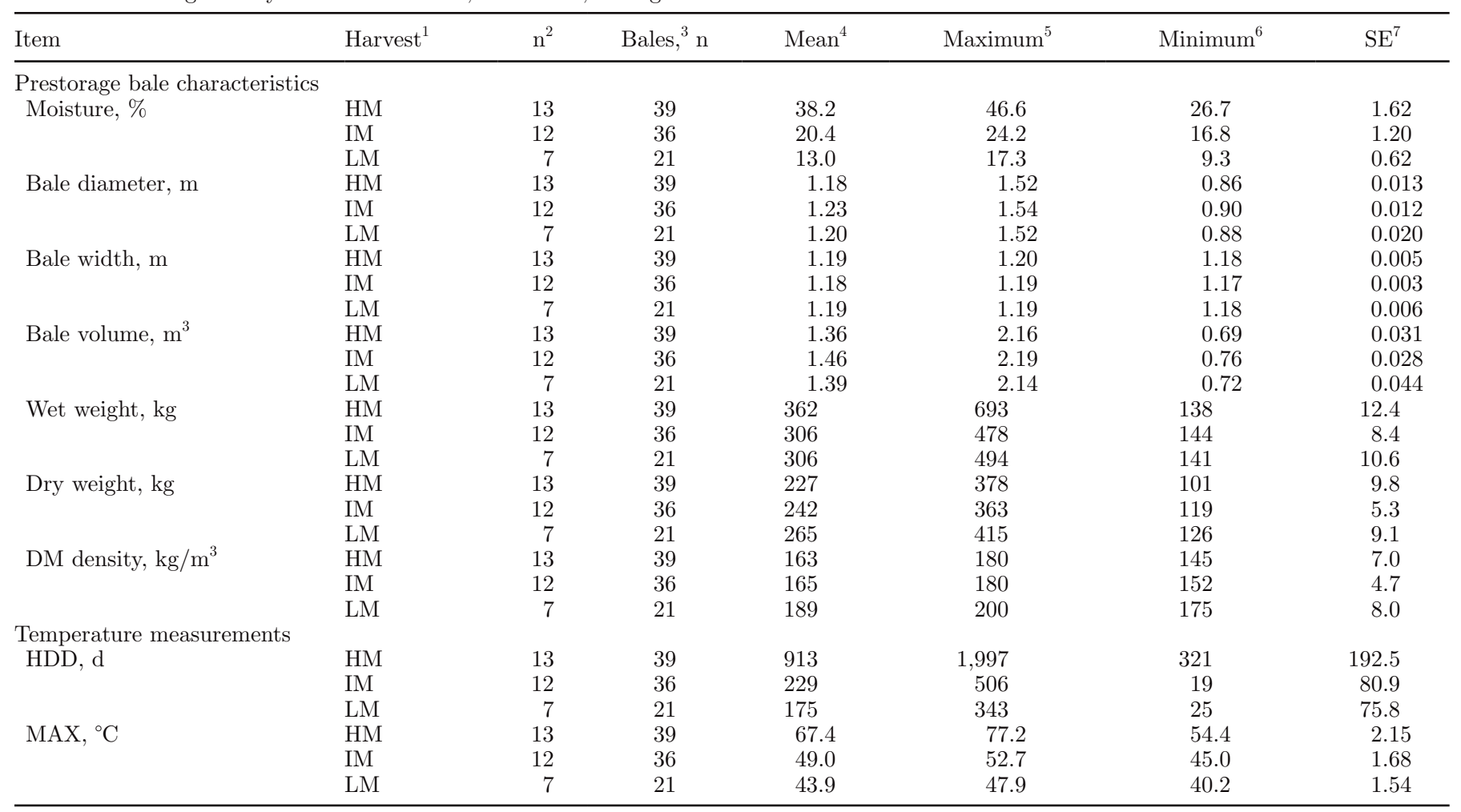

${ }^{1}$ Harvest: $\mathrm{HM}=$ high moisture (26.7 to $46.6 \%$ ); IM = intermediate moisture (16.8 to $24.2 \%$ ); and LM = low moisture (9.3 to $17.3 \%$ ).

${ }^{2}$ Number of interactive treatments during each harvest. Harvest HM contained one baling treatment made at $26.7 \%$ moisture at the $0.9-\mathrm{m}$ bale diameter only, whereas LM contained a dry control made at $9.3 \%$ moisture and at the $1.2-\mathrm{m}$ bale diameter only. These additional treatments were made only at one diameter because insufficient forage was available to complete the entire factorial arrangement of treatments (bale diameters) at these moisture concentrations. Each interactive treatment represents the mean of 3 bales.

${ }^{3}$ Total number of bales made per harvest.

${ }^{4}$ Overall mean of all interactive bale moisture $\times$ bale diameter treatments.

${ }^{5}$ Maximum value across all interactive treatments.

${ }^{6}$ Minimum value across all interactive treatments.

${ }^{7}$ Standard error of the interactive mean.

Prestorage Sampling and Processing. Immediately after packaging, bales from the LM harvest were weighed by using a hanging digital scale that was fastened to the front-end loader of a tractor. For the IM and HM harvests, bales were weighed on a customized feed cart equipped with load cells to decrease processing time immediately after baling. For each hay harvest, bale width and diameter were determined with a tape measure, thereby allowing the calculation of bale volume and DM density. At the same time, nine 0.46-m-deep cores (0.025-m diameter) were taken from the center portion of one side of each bale using a Uni-Forage Sampler (Star Quality Samplers, Edmonton, Alberta, Canada). All holes created during this initial sampling were filled immediately with spray-foam insulation to prevent air, sunlight, and moisture from having direct access to the bale core and to eliminate avenues for quick dissipation of heat and moisture from the bale. Hay samples
( $\sim 400 \mathrm{~g})$ from each bale were mixed thoroughly and then dried to constant weight under forced air at $50^{\circ} \mathrm{C}$ to determine the prestorage concentration of moisture for each bale. These samples were then retained for subsequent analysis of whole-plant ash and IVTD, as well as subsequent determination of in situ disappearance kinetics of DM. Following initial processing, all bales were placed on wooden pallets located outdoors on a dense grass sod. Pallets were placed approximately $2 \mathrm{~m}$ apart to allow air and light to penetrate to the soil surface.

\section{Temperature Measurements}

After initial processing, each bale was fitted with a thermocouple positioned near its geometric center. Bale temperatures were taken once daily at approximately $1300 \mathrm{~h}$ using an Omega 450 AKT Type K thermocouple 
thermometer (Omega Engineering, Stamford, CT), and then evaluated for maximum internal bale temperature (MAX) over the storage period. Heating degree days $>30^{\circ} \mathrm{C}(\mathbf{H D D})$ were computed as the summations of the daily increment by which the internal bale temperature was greater than $30^{\circ} \mathrm{C}$. Therefore, HDD accumulated during storage should be viewed as a single numeric response variable that integrated both the intensity and duration of spontaneous heating within each bale. Collections of temperature data were terminated for the LM, IM, and HM harvests on September 25, 2006, October 22, 2007, and December 14, 2006, respectively, when bales no longer exhibited any evidence of active heating.

\section{Poststorage Sampling and Processing}

After temperature measurements were terminated, all bales were measured for width and diameter and weighed a second time. Recoveries of DM for each bale were calculated based on differences in DM weights before and after storage. Unlike the sampling protocol for bales before storage, poststorage core-sampling procedures were more rigorous and were dependent on bale diameter. The surface layer of all bales, regardless of diameter, was sampled to a depth of $0.15 \mathrm{~m}$. This procedure was used to eliminate confounding between individual harvests that could be created by differences in temperature, rainfall, air movement, and other weather-related variables during the outdoor storage periods for each harvest. The 0.15-m-deep, surface-layer sample for each bale was a thoroughly mixed composite of 24 probes spaced uniformly over the entire half of the bale surface that was directly opposite that of prestorage sampling sites. Deep-core samples were then taken with a $0.61-\mathrm{m}$ probe for the $1.2-$ and $1.5-\mathrm{m}$ bales, and with a $0.46-\mathrm{m}$ probe for the $0.9-\mathrm{m}$ bales. To prevent contamination of the core samples with hay from the surface layer, the 24 surface-layer probes were taken first, and then the deep-core samples were extracted from the same sampling holes. Respective totals of approximately $250 \mathrm{~g}$ and $1,000 \mathrm{~g}$ of sample were composited from the 24 surface and deep-core probe sites obtained from each bale. All samples were dried to constant weight under forced air $\left(50^{\circ} \mathrm{C}\right)$ to determine the concentration of moisture within each poststorage bale layer, and then retained for evaluation of whole-plant ash, IVTD, and in situ disappearance kinetics of DM.

\section{Laboratory Analyses}

Portions of each dried hay sample were ground through a Wiley mill (Arthur H. Thomas, Philadelphia, PA) equipped with either a 1- or 2-mm screen. The portion ground through the 1-mm screen was retained in sealed freezer bags for analysis of whole-plant ash and IVTD. Portions ground through the 2-mm screen were retained similarly for subsequent ruminal in situ incubations. Concentrations of whole-plant ash were determined for each sample following combustion of $1.0-\mathrm{g}$ samples in a muffle furnace at $500^{\circ} \mathrm{C}$ for $2 \mathrm{~h}$. Procedures and apparatus for determining IVTD consisted of incubating a $0.5-\mathrm{g}$ sample in a 125-mL Erlenmeyer flask containing rumen fluid, buffer media, and macroand micro-mineral solutions for $48 \mathrm{~h}$ (Goering and Van Soest, 1970). Incubation flasks were maintained in a water bath at $39^{\circ} \mathrm{C}$ and were purged continuously with $\mathrm{CO}_{2}$. Rumen fluid was harvested from a nonlactating dairy cow fitted with a ruminal cannula and fed a diet containing $69 \%$ alfalfa-grass silage, $30 \%$ corn silage, with the balance consisting of vitamin and mineral supplements. Rumen fluid was maintained at $39^{\circ} \mathrm{C}$ in insulated vessels purged with $\mathrm{CO}_{2}$, mixed in a blender also purged with $\mathrm{CO}_{2}$, and then strained through 3 layers of cheesecloth before blending with other elements of the incubation medium. After $48 \mathrm{~h}$, incubations were terminated by digestion in neutral-detergent solution (Goering and Van Soest, 1970; Mertens, 1992) that included both heat-stable $\alpha$-amylase and sodium sulfite.

\section{In Situ Incubation Procedures}

Selection of Hays. To reduce the number of hays to a manageable number for in situ analysis, 18 interactive (bale moisture $\times$ bale diameter) treatments from the HM (10 treatments) and IM harvests (8 treatments) were selected for further study. All hays consisted of forage from the bale core only; surface samples, which were exposed directly to varying weather conditions, were not evaluated in situ. In addition, each hay treatment was composited over the 3 like-field replications (bales) before conducting kinetic evaluations. The 18 treatments were selected to represent the entire range of heating characteristics exhibited over the IM and HM harvests, and to provide the best possible distribution of treatments across this entire heating continuum. To provide a clear contrast with kinetic characteristics from prestorage hays, 2 additional composites were evaluated; these included a composite derived from prestorage samples obtained from the 10 hays selected from the HM harvest, and another prestorage composite derived from the 8 hays selected from the IM harvest. Although hays from the LM harvest were evaluated for DM recovery, IVTD, and whole-plant ash, they were not included among the hays selected for in situ analysis. This was a procedural compromise necessitated by the upper limit of about 20 hays that could be evaluated simultaneously using in situ techniques. We chose to 
eliminate hays from the LM harvest because they did not extend the range of accumulated HDD (25 to 343 HDD) relative to the IM harvest (19 to 506 HDD), nor did they substantially improve the uniform distribution of HDD within these ranges. In addition, hays from the LM harvest contained a somewhat greater percentage of alfalfa (91\%) relative to the IM $(76 \%)$ and HM $(68 \%)$ harvests; as a result, the mean prestorage concentrations of IVTD for the IM and HM harvests were essentially identical (76.7 and $76.3 \%$, respectively), whereas that observed for the LM harvest was slightly greater $(79.4 \%)$.

Animal Care. Two nonlactating $937 \pm 35.4-\mathrm{kg}$ ruminally cannulated Holstein cows were used for the ruminal incubations of heated hays. Cannulations (protocol \#A-1307) and care of the cows (protocol \#A-1339) were approved by the Research Animal Resources Center of the University of Wisconsin. Cows were housed in individual $4.3-\times 8.5-\mathrm{m}$ pens with concrete floors that were bedded with wood shavings and cleaned regularly. A basal diet consisting of chopped alfalfa/quackgrass hay $(14.0 \% \mathrm{CP}, 50.8 \% \mathrm{NDF}$, and $36.0 \% \mathrm{ADF})$, ground corn, and trace-mineralized salt was offered in equal portions at 0900 and $1500 \mathrm{~h}$ at a daily cumulative rate of $1.35 \%$ of BW. On an as-fed basis, the basal diet contained $90.3 \%$ alfalfa/grass hay, $8.9 \%$ ground corn, and $0.8 \%$ trace-mineralized salt; ground corn and salt were top-dressed at each feeding. Fresh water was available continuously on an ad libitum basis, and the cows were adapted to the basal diet for $10 \mathrm{~d}$ before initiating the trial. Experimental hays were evaluated during 2 periods. After the 10-d adaptation to the basal diet, in situ analyses were conducted in both cows over a 4-d time interval (period 1). Following period 1, cows were given a 3-d recovery period before initiating identical procedures during period 2 .

Incubation Procedures. In situ procedures were consistent with the standardized techniques described by Vanzant et al. (1998). Five-gram samples of each dried forage were weighed into Dacron bags $(10 \mathrm{~cm}$ $\times 20 \mathrm{~cm} ; 50 \pm 10-\mu \mathrm{m}$ pore size; Ankom Technology Corp.) that were heat-sealed with an impulse sealer (Type TISH-200, TEWI International Co. Ltd., Taipei, Taiwan). Before insertion into the rumen, all Dacron bags were placed in $35-\times 50-\mathrm{cm}$ mesh bags and incubated in tepid water $\left(39^{\circ} \mathrm{C}\right)$ for $20 \mathrm{~min}$. Samples were then suspended in the ventral rumen at $0700 \mathrm{~h}$ and incubated for $3,6,9,12,24,36,48,72$, or $96 \mathrm{~h}$. Upon removal from the rumen, bags were rinsed immediately in a top-loading washing machine. Rinsing procedures included 10 cold-water rinse cycles, in which each cycle consisted of $1 \mathrm{~min}$ of agitation and $2 \mathrm{~min}$ of spin (Coblentz et al., 1997b; Vanzant et al., 1998). A separate set of bags was preincubated and rinsed with- out ruminal incubation $(0 \mathrm{~h})$. After rinsing, the sample residues were dried to a constant weight under forced air at $50^{\circ} \mathrm{C}$, and then equilibrated with the atmosphere in the laboratory before determination of residual DM (Vanzant et al., 1996). Using these procedures, the entire study comprised 800 Dacron bags. Allocation of bags and time periods was identical across animals and experimental periods. Therefore, for each of the 4 animal $\times$ period combinations, there were 200 total Dacron bags (20 hays $\times 10$ time periods); of these, 180 bags were incubated within the ventral rumen and 20 represented the $0-\mathrm{h}$ bags that were presoaked and rinsed without ruminal incubation.

The percentage of DM remaining at each incubation time was fitted to the nonlinear regression model of Mertens and Loften (1980) using PROC NLIN (SAS Institute, 1990). Forage DM was partitioned into 3 fractions based on relative susceptibility to ruminal disappearance. Fraction A was defined as the percentage of DM that disappeared from Dacron bags at a rate too fast to measure. Fraction B represented the portion of DM that disappeared at a measurable rate; and fraction $\mathrm{C}$ was defined as the portion of $\mathrm{DM}$ that was unavailable in the rumen. Fractions B and C, disappearance rate $\left(\mathbf{K}_{\mathrm{d}}\right)$, and the discrete lag time were determined directly by the nonlinear regression model. For each forage, fraction A was calculated as 100\% - (B $+\mathrm{C})$, and the effective ruminal disappearance of DM was calculated as $\mathrm{A}+\mathrm{B} \times\left[\mathrm{K}_{\mathrm{d}} /\left(\mathrm{K}_{\mathrm{d}}+\mathrm{Kp}\right)\right]$ (Ørskov and McDonald, 1979), where $\mathrm{Kp}=$ passage rate, which was set arbitrarily at $0.06 / \mathrm{h}$ to make the results most relevant to lactating dairy cows (Hoffman et al., 1993). An independent ruminal DM decay curve was fitted for each combination of animal, period, and forage, resulting in a total of $80 \mathrm{DM}$ decay curves for the entire project.

\section{Statistics}

LM, IM, and HM Harvests. Initially, data evaluating the randomized fixed effects of bale moisture and diameter within each specific harvest were analyzed independently (data not shown). Based on these initial statistical analyses, we concluded that bale moisture and density affected DM recovery, concentrations of ash and IVTD, as well as in situ disappearance characteristics of DM through mechanisms that were primarily indirect. Conceptually, if bale moisture or bale diameter affected concentrations of ash or IVTD directly, there likely would be supporting evidence in samples taken immediately after baling. For example, low bale moisture could have a direct effect on concentrations of IVTD by increasing leaf shatter; however, there was no evidence of these responses immediately after baling 
within the ANOVA of any individual study (data not shown). Originally, it was our intention to analyze and report on each harvest as an independent randomized fixed-effect trial, and then combine the data from the 3 harvests by regressing response variables on indices of spontaneous heating (HDD and MAX). However, these statistical approaches proved to be largely redundant, primarily because varying bale moisture and diameter within each harvest created a range of conditions that were more or less favorable for microbial respiration, spontaneous heating, and the subsequent retention of heat within each bale. To attain the most concise presentation of results, analyses of individual harvests as fixed-effect trials have been omitted, and HDD and MAX are used as continuous independent variables that integrate results from all 3 harvests into a single combined presentation.

Regressions of HDD and MAX on Prestorage Bale Moisture. To best describe the relationships between measures of spontaneous heating (HDD and MAX) and bale moisture before storage, 32 means that each represented a specific interactive combination of bale moisture and bale density were pooled from the LM, IM, and HM harvests and regressed against the corresponding concentrations of prestorage bale moisture. Both linear and quadratic models were evaluated using PROC REG (SAS Institute, 1990). Tests of homogeneity (PROC GLM; SAS Institute, 1990) were performed to assess whether slopes and intercepts differed across bale diameters; if this occurred, a separate linear regression was reported for each bale diameter.

Regressions of DM Recovery, Ash, and IVTD on $H D D$ and $M A X$. Dry matter recovery was related to HDD and MAX by linear regression techniques (PROC REG; SAS Institute, 1990). Thirty-two interactive means that each represented a specific combination of bale moisture and bale density were again pooled from the LM, IM, and HM harvests, and regressed against the corresponding heat increments incurred by those treatments during storage. As described previously, tests of homogeneity (PROC GLM; SAS Institute, 1990) were performed to assess whether slopes and intercepts differed across bale diameters. If this occurred, a separate linear regression was reported for each bale diameter.

For concentrations of whole-plant ash and IVTD, 32 interactive means were pooled from the LM, IM, and HM harvests and regressed against measures of spontaneous heating; however, the prestorage concentrations of ash and IVTD from the 3 harvests were not identical. To eliminate confounding and normalize data across the 3 harvests, concentrations of ash and IVTD within the bale core were expressed as a mathematical difference (poststorage - prestorage; $\mathbf{\Delta A S H}$ and $\mathbf{\Delta I V T D ,}$, re- spectively). These baseline-adjusted response variables were then regressed against measures of spontaneous heating using various nonlinear or polynomial regression models. These included nonlinear regression models (PROC NLIN; SAS Institute, 1990) of the general form $Y=b \times\left(e^{-k x}\right)-a$, if concentrations of ash or IVTD declined with spontaneous heating $(\triangle \mathrm{ASH}$ or $\Delta$ IVTD were negative), or $Y=a-\left(b \times e^{-k x}\right)$, if concentrations of ash or IVTD increased with heating $(\triangle \mathrm{ASH}$ or $\Delta$ IVTD were positive). For these model assessments, $k$ was defined as the rate constant, $x$ as the independent variable (HDD or MAX), and $a$ and $b$ were parameters determined directly by the regression model. During nonlinear model assessment, independent variables (HDD or MAX) also were squared to determine if that improved fit. In practice, these nonlinear regression models were more difficult to apply when MAX was the independent variable; in part, this resulted from the distribution of the MAX measurement itself. For hay experiments of this type, $\operatorname{MAX}=0^{\circ} \mathrm{C}$ is always nonsensical, and the overall range for MAX in the present studies was from 40.2 to $77.2^{\circ} \mathrm{C}$, with no data distributed between MAX $=0$ and $40.2^{\circ} \mathrm{C}$. In addition, 4 other polynomial models (linear, quadratic, cubic, and quartic effects of HDD or MAX) also were evaluated by PROC REG (SAS Institute, 1990).

Generally, coefficients of determination $\left(\mathrm{r}^{2}\right.$ or $\left.\mathrm{R}^{2}\right)$ were used to determine the most appropriate model; however, polynomial regressions were not selected if the coefficient or slope for the highest ordered term did not differ from zero, or if the best polynomial fit included an illogical inflection in the regression curve that could not be explained biologically.

Regressions of DM Kinetic Characteristics on $H D D$ and $M A X$. Before initiating regression procedures, fractions $\mathrm{A}, \mathrm{B}$, and $\mathrm{C}$, as well as lag time, $\mathrm{K}_{\mathrm{d}}$, and effective degradability were subjected to ANOVA procedures, thereby generating a mean response for each kinetic parameter over the 4 combinations of animal and period. As described previously for IVTD and whole-plant ash, these mean kinetic parameters were then normalized across IM and HM hay harvests by expressing each as a mathematical (baseline-adjusted) difference resulting from storage (poststorage - prestorage; $\Delta \mathrm{A}, \Delta \mathrm{B}, \Delta \mathrm{C}, \Delta \mathrm{LAG}, \Delta \mathrm{K}_{\mathrm{d}}$, and $\Delta \mathrm{DEG}$, respectively). The pool of regression models considered was identical to those described previously for $\Delta \mathrm{ASH}$ and $\triangle I V T D$, as was the selection criteria for the most appropriate model. Throughout all regression analyses, significance was declared at $P \leq 0.05$, unless otherwise indicated. It should be noted clearly that these regression techniques are meant only to describe the changes during storage as a function of HDD and MAX; it should not be inferred that these procedures are suf- 
ficiently rigorous to extrapolate beyond the context of this data set, or to serve as a direct basis for estimating values for unknown forages.

\section{RESULTS AND DISCUSSION}

\section{Temperature Accumulation During Bale Storage}

Temperature data (HDD and MAX) from the 3 harvests are summarized for individual harvests in Table 1. As observed in many other studies (Rotz and Muck, 1994), the moisture concentration of the hay at the time it was baled positively influenced subsequent heat development during storage. After combining data from LM, IM, and HM harvests (Figure 1), tests of homogeneity indicated that slopes $(P<0.001)$ and intercepts $(P<0.001)$ relating HDD with prestorage concentrations of bale moisture differed across the 0.9-, $1.2-$, and $1.5-\mathrm{m}$ bale diameters. Heating degree days $>30^{\circ} \mathrm{C}$ for both $0.9-$ and $1.2-\mathrm{m}$ bales exhibited positive linear relationships with prestorage bale moisture (Figure 1A). Intercepts for these 2 bale types differed $(P=$ $0.003)$ and slopes tended to differ $(P=0.067)$ with the larger bales accumulating $26.9 \mathrm{HDD} /$ percentage unit of moisture compared with 19.1 HDD/percentage unit of moisture for the smaller $(0.9-\mathrm{m})$ bales. In contrast, the 1.5-m bales accumulated HDD in a quadratic relationship $\left(\mathrm{y}=0.99 \mathrm{x}^{2}-82 ; \mathrm{R}^{2}=0.957\right)$ with bale moisture that was best fit without the linear term. Bales made at the 1.5-m diameter accumulated a maximum of 1,997 HDD, which nearly doubled the maximum accumulation for 1.2-m bales (1,005 HDD) and largely explains the departure from linearity, especially for wet hays. Although the response for the 1.5-m bales exhibited the greatest coefficient of determination, linear models for $0.9-$ and $1.2-\mathrm{m}$ bales also explained nearly $90 \%$ of the variation in the data $\left(\mathrm{r}^{2}=0.895\right.$ and 0.880 , respectively). For MAX (Figure 1B), tests of homogeneity indicated that a common slope $\left(P=0.188 ; 0.93^{\circ} \mathrm{C} /\right.$ percentage unit of prestorage bale moisture) was observed across all bale diameters, but intercepts differed $(P=0.004)$. However, positive linear relationships were observed in all cases, and coefficients of determination were very high $\left(r^{2}=0.943\right.$ to 0.971$)$, again indicating that prestorage bale moisture was the primary factor affecting spontaneous heating in large-round bales. Previously, linear relationships between spontaneous heating and prestorage bale moisture have been reported for small rectangular bales of bermudagrass (Cynodon dactylon [L.] Pers.) packaged at concentrations of moisture ranging from 17.8 to $32.5 \%$ (Coblentz et al., 2000); as observed in our 0.9- and 1.2-m bales, responses for these smaller rectangular hay packages were also void of statistically significant curvilinear character.
The positive effect of bale diameter on accumulations of HDD likely results from 2 physical factors. Previously, Rotz and Muck (1994) theorized that heat developed per unit of DM is nearly independent of bale density, thereby suggesting that more heat is developed in dense bales simply because more DM has been compressed into the bale package. Although bale density was not a treatment factor in our studies, bale diameter may have a similar positive effect on heat development simply by increasing the amount of DM physically packaged within each bale. In addition, bale diameter may positively affect heating characteristics by reducing the amount of surface area per kilogram of forage $\mathrm{DM}$, thereby increasing resistance to the dissipation of heat. For example, within the HM harvest, the prestorage ratio of surface area to DM was $0.025 \mathrm{~m}^{2} / \mathrm{kg}$ of DM for 1.5-m diameter bales, but nearly twice as large for $0.9-\mathrm{m}$ bales $\left(0.043 \mathrm{~m}^{2} / \mathrm{kg}\right.$ of $\left.\mathrm{DM}\right)$. This second factor may explain the contrasting responses observed in regressions of HDD and MAX on prestorage bale moisture. Maximum internal bale temperature is a singlepoint-in-time estimate, often occurring during a period of intense respiratory activity relatively early in the storage period (Montgomery et al., 1986; Coblentz et al., 1996). As such, this measurement is likely to be less affected by differences in the surface area per kilogram of DM that may affect retention of heat or moisture within the bale. Within this context, bale diameter did not affect $(P=0.188)$ linear slopes in regressions of MAX on prestorage bale moisture, although the slope for $1.5-\mathrm{m}$ bales $\left(1.03^{\circ} \mathrm{C} /\right.$ percentage unit of moisture) was numerically greater than observed for the 0.9and $1.2-\mathrm{m}$ bales $\left(0.90\right.$ and $0.86^{\circ} \mathrm{C} /$ percentage unit of moisture, respectively). In contrast, accumulations of HDD are sensitive to modestly elevated temperatures maintained over a much longer period, and therefore are affected more directly by physical factors such as the ratio of surface area per kilogram of DM, which was evident from the distinctly divergent responses across bale diameters within regressions of HDD on prestorage bale moisture (Figure 1A).

\section{Poststorage Bale Characteristics}

All physical bale characteristics following storage for the HM, IM, and LM harvests are summarized in Table 2. Most notably, final concentrations of moisture at the bale surface and core varied across harvests, in part because of the diversity of baling moistures across harvests, but also because of varying weather conditions during the outdoor-storage period following each harvest. For the HM harvest, final concentrations of moisture at the bale surface (range $=20.3$ to $32.6 \%$ ) and core (range $=16.9$ to $29.8 \%$ ) suggest that even 

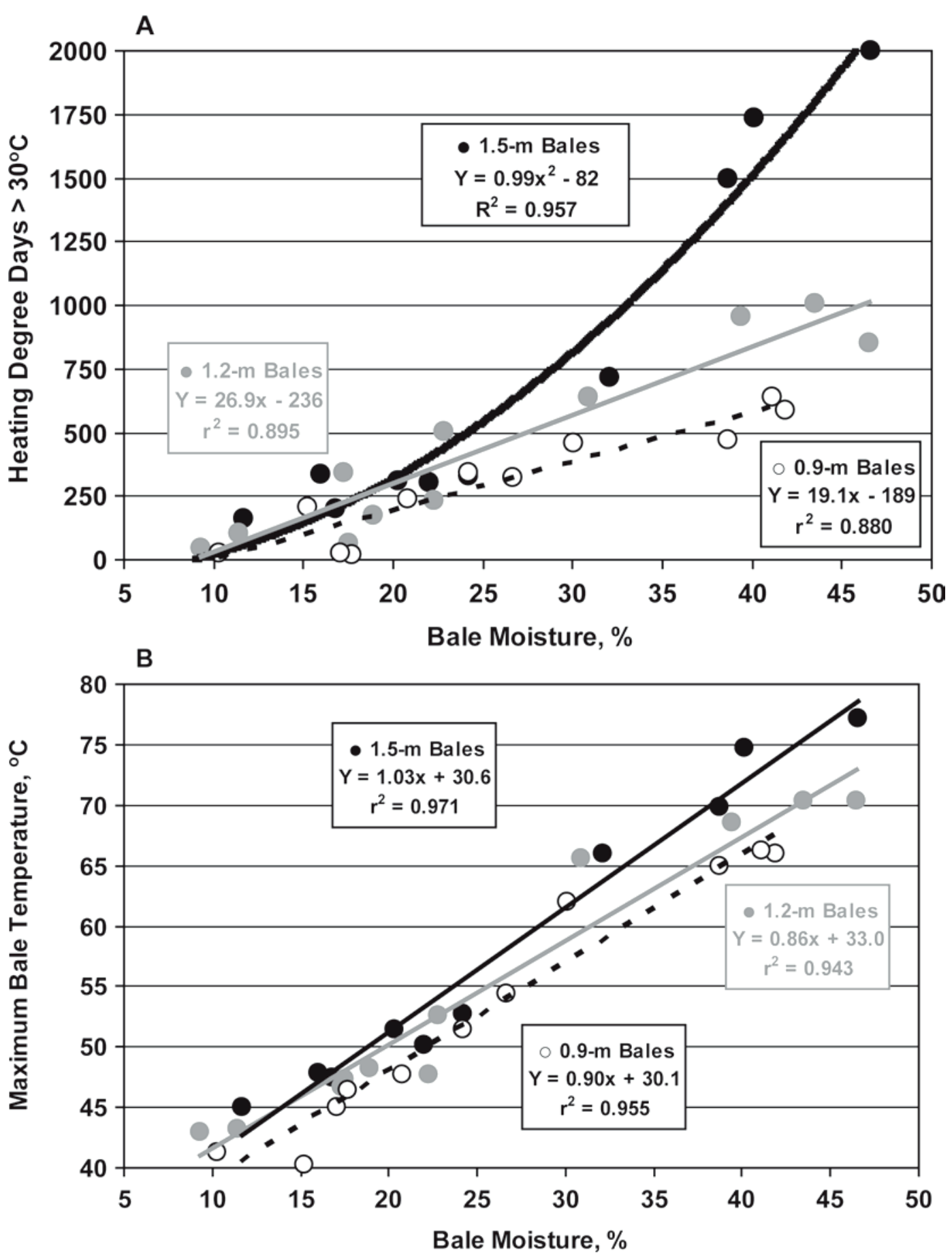

Figure 1. Regressions of heating degree days $>30^{\circ} \mathrm{C}(\mathrm{A})$ and maximum internal bale temperature (B) on concentrations of initial bale moisture for high-, intermediate-, and low-moisture harvests. Regressions were not homogeneous across the 1.5- (black line and circles), 1.2- (gray line and circles), and 0.9-m (dashed line and open circles) diameter bales; therefore, regression lines and equations are reported independently.

after $106 \mathrm{~d}$ in storage, cessation of heating occurred because of cold ambient temperatures (December 2006 mean $=-3.6^{\circ} \mathrm{C}$; NOAA, 2006), rather than dissipation of moisture from the bale. For the IM harvest, the most noteworthy response was the relatively large discrepancy between final moisture concentrations at the bale surface and core (overall means $=24.7$ and $13.3 \%$, respectively), which likely can be explained by the $189-\mathrm{mm}$ precipitation surplus that occurred during the August, September, and October 2007 stor- 
Table 2. Poststorage bale characteristics for round bales of alfalfa-orchardgrass hay made at Stratford, Wisconsin, during 2006 and 2007

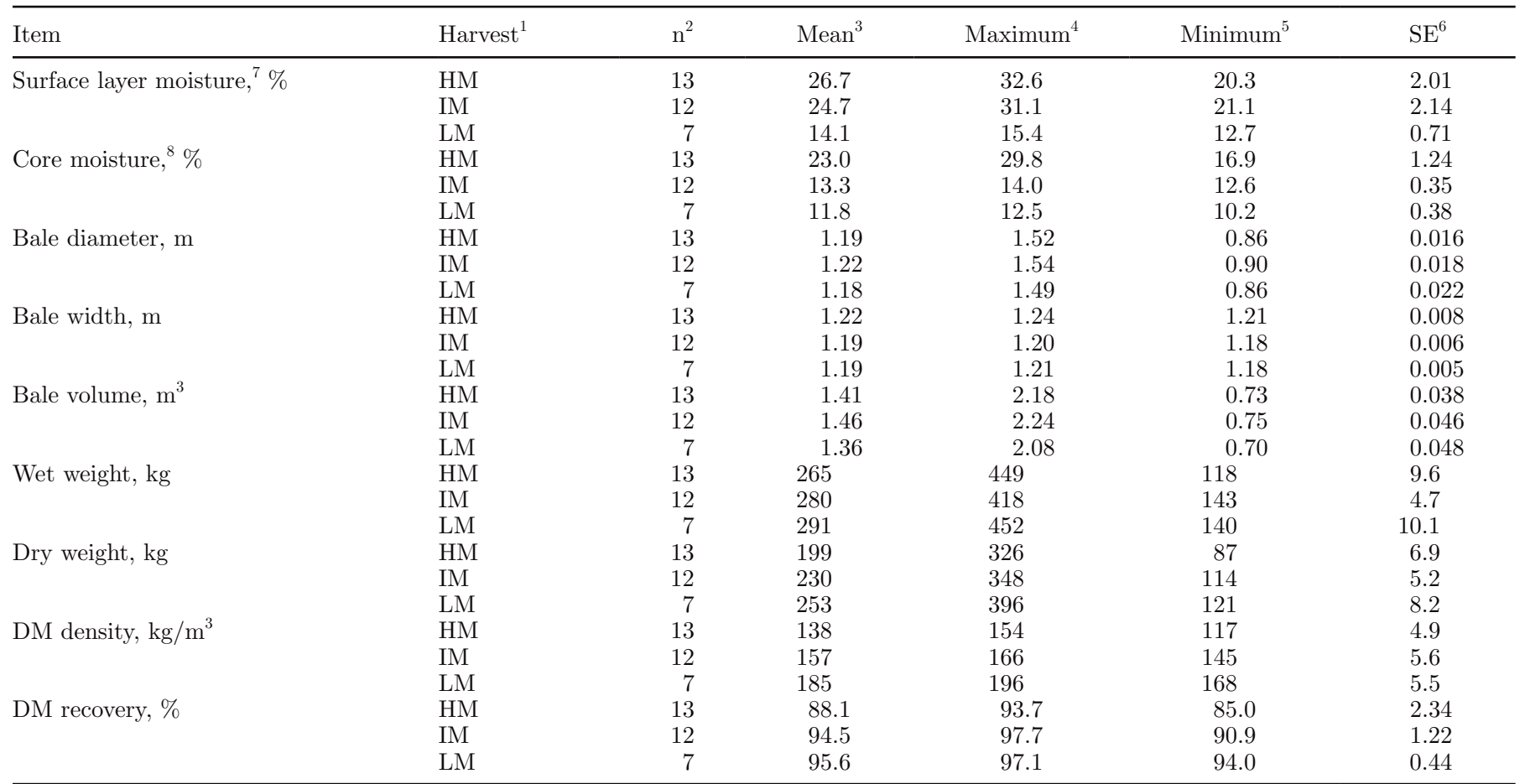

${ }^{1}$ Harvest: $\mathrm{HM}=$ high moisture (26.7 to $\left.46.6 \%\right)$; IM = intermediate moisture (16.8 to $24.2 \%$ ); and LM = low moisture (9.3 to $\left.17.3 \%\right)$.

${ }^{2}$ Number of interactive treatments during each harvest. Harvest HM contained one baling treatment made at $26.7 \%$ moisture at the $0.9-\mathrm{m}$ bale diameter only, whereas LM contained a dry control made at $9.3 \%$ moisture and at the $1.2-\mathrm{m}$ bale diameter only. These additional treatments were made only at one diameter because insufficient forage was available to complete the entire factorial arrangement of treatments (bale diameters) at these moisture concentrations. Each interactive treatment represents the mean of 3 bales.

${ }^{3}$ Overall mean of all interactive bale moisture $\times$ bale diameter treatments.

${ }^{4}$ Maximum value across all interactive treatments.

${ }^{5}$ Minimum value across all interactive treatments.

${ }^{6}$ Standard error of the interactive mean.

${ }^{7}$ Moisture concentration of the 0.15 -m-deep surface layer.

${ }^{8}$ Moisture concentration of the bale core.

age interval (NOAA, 2007). Bales made from the LM harvest exhibited relatively minor overall differences in moisture concentration between the bale surface (overall mean $=14.1 \%$ ) and core $(11.8 \%)$; this can be explained by the relatively low prestorage moisture content of these bales (9.3 to $17.3 \%$; Table 1), as well as a $93-\mathrm{mm}$ precipitation deficit that occurred during July, August, and September of 2006 (NOAA, 2006), which comprised the majority of the storage period for these bales.

\section{Recoveries of DM}

Regressions of DM recoveries on HDD and MAX for 32 interactive treatment combinations of bale moisture and diameter (Table 3) indicated that recoveries of DM are related closely to heating characteristics. When regressed on $\mathrm{HDD}$, tests of homogeneity indicated that both slopes $(P<0.001)$ and intercepts $(P<0.001)$ differed across bale diameters; the most negative slope $(-0.016$ percentage units of DM/HDD) was observed for $0.9-\mathrm{m}$ bales, whereas the slowest change per HDD $(-0.006$ percentage units of $\mathrm{DM} / \mathrm{HDD})$ was exhibited by bales made in the largest (1.5-m) packages. For $0.9-\mathrm{m}$ diameter bales, the rapid loss of DM per HDD is likely associated with greater surface area per kilogram of DM, which probably facilitated more rapid dissipation of heat, thereby depressing the accumulation of HDD. Overall, coefficients of determination $\left(\mathrm{r}^{2}\right)$ for these linear regressions were quite high $\left(r^{2} \geq 0.872\right)$, regardless of bale diameter, indicating that HDD is a very effective indicator of DM recovery (or loss) from largeround bales within any specific bale diameter. When MAX was used as the independent variable, slopes were homogeneous $(P=0.830)$ across bale diameters with a common slope of -0.32 percentage units of $\mathrm{DM} /{ }^{\circ} \mathrm{C}$; intercepts differed $(P=0.001)$ across bale diameters, but the overall range was narrow (110.4 to $112.4 \%$ ). 
Table 3. Regressions of DM recoveries (\%) on heating degree days $>30^{\circ} \mathrm{C}$ (HDD) and maximum internal bale temperature (MAX) for bale moisture $\times$ bale diameter interaction means pooled from 3 harvests conducted during 2006 and 2007 near Stratford, Wisconsin

\begin{tabular}{lcccccccc}
\hline Heating index & Bale diameter, $\mathrm{m}$ & $\mathrm{n}^{1}$ & Slope & $\mathrm{SE}_{\text {Slope }}{ }^{2}$ & Intercept & $\mathrm{SE}_{\text {Intercept }}{ }^{3}$ & $\mathrm{r}^{2}$ & $P$-value \\
\hline HDD & 1.5 & 10 & $-0.006^{5}$ & 0.0005 & $97.2^{6}$ & 0.52 & 0.951 & $<0.001$ \\
& 1.2 & 11 & -0.010 & 0.0012 & 97.5 & 0.68 & 0.891 & $<0.001$ \\
MAX, ${ }^{\circ} \mathrm{C}$ & 0.9 & 11 & -0.016 & 0.0021 & 96.0 & 0.77 & 0.872 & $<0.001$ \\
& 1.5 & 10 & -0.34 & 0.054 & $112.4^{6}$ & 3.23 & 0.834 & $<0.001$ \\
& 1.2 & 11 & -0.32 & 0.048 & 110.4 & 2.67 & 0.833 & $<0.001$ \\
\hline
\end{tabular}

${ }^{1}$ Each interactive treatment is the mean of 3 bales.

${ }^{2}$ Standard error of the slope.

${ }^{3}$ Standard error of the intercept.

${ }^{4}$ Probability that the slope $=0$.

${ }^{5}$ Slopes differed across bale diameters $(P<0.001)$.

${ }^{6}$ Intercepts differed across bale diameters $(P=0.001)$.

As observed for regressions on HDD, coefficients of determination were high $\left(r^{2} \geq 0.833\right)$, regardless of bale diameter.

\section{Ash}

Whole-plant ash is retained as a consequence of spontaneous heating (Rotz and Muck, 1994), and concentrations typically increase indirectly as nonstructural carbohydrates are oxidized. Within the surface layer of bales stored outdoors, this process can be further complicated by the preferential leaching of carbohydrates during rainfall events (Collins et al., 1987). Summaries of the HM, IM, and LM harvests (Table 4) indicate that concentrations of ash were numerically greater at the bale core for all harvests compared with concentrations observed at baling; however, the mean overall differential (1.9 percentage units) was greatest for the
HM harvest, which is consistent with the more extreme heating characteristics within those bales (Table 1). For the IM harvest, the mean final concentration of ash at the bale surface (10.9\%) was numerically greater than that observed at the bale core (10.4\%), and this likely reflects the $189-\mathrm{mm}$ precipitation surplus that occurred during August, September, and October of 2007 (NOAA, 2007), which comprised most of the storage period for these bales. Accumulation of ash is important because ash contains no energy, and is therefore subtracted from total plant DM during estimation of nonfiber carbohydrate and subsequent calculation of total digestible nutrients by summative equation (Weiss et al., 1992; NRC, 2001). Regressions of $\Delta \mathrm{ASH}$ on HDD (Figure 2A) and MAX (Figure 2B) were best fit by quadratic and linear models, respectively, in which $\triangle \mathrm{ASH}$ became increasingly positive with either index of spontaneous heating. In both cases, the model

Table 4. Concentrations of whole-plant ash and in vitro true digestibility (IVTD) for round bales of alfalfa-orchardgrass hay made during 2006 and 2007 at Stratford, Wisconsin

\begin{tabular}{|c|c|c|c|c|c|c|c|c|c|c|}
\hline Item & Harvest $^{1}$ & $\mathrm{n}^{2}$ & \multicolumn{2}{|c|}{ Prestorage } & \multicolumn{2}{|c|}{ Poststorage surface } & \multicolumn{4}{|c|}{ Poststorage core } \\
\hline \multirow[t]{2}{*}{ Ash, $\%$} & HM & 13 & 12.5 & 0.11 & 14.4 & 0.21 & 14.4 & 16.1 & 12.8 & 0.70 \\
\hline & LM & 7 & 11.2 & 0.13 & 11.7 & 0.18 & 11.7 & 12.2 & 11.0 & 0.34 \\
\hline \multirow[t]{2}{*}{ IVTD, $\%$} & HM & 13 & 76.4 & 0.21 & 70.9 & 0.23 & 70.7 & 73.4 & 68.2 & 0.95 \\
\hline & IM & 12 & 76.7 & 0.28 & 72.7 & 0.37 & 74.9 & 77.0 & 72.8 & 0.79 \\
\hline
\end{tabular}

${ }^{1}$ Harvest: $\mathrm{HM}=$ high moisture (26.7 to $\left.46.6 \%\right)$; IM = intermediate moisture (16.8 to $24.2 \%$ ); and LM = low moisture (9.3 to $\left.17.3 \%\right)$.

${ }^{2}$ Number of interactive treatments during each harvest. Harvest HM contained one baling treatment made at $26.7 \%$ moisture at the 0.9 -m bale diameter only, whereas LM contained a dry control made at $9.3 \%$ moisture and at the 1.2-m bale diameter only. These additional treatments were made only at one diameter because insufficient forage was available to complete the entire factorial arrangement of treatments (bale diameters) at these moisture concentrations. Each interactive treatment represents the mean of 3 bales.

${ }^{3}$ Overall mean of all interactive bale moisture $\times$ bale diameter treatments.

${ }^{4}$ Standard error of the overall mean of all interactive bale moisture $\times$ bale diameter treatments.

${ }^{5}$ Maximum value across all interactive treatments.

${ }^{6}$ Minimum value across all interactive treatments.

${ }^{7}$ Standard error of the interactive mean. 

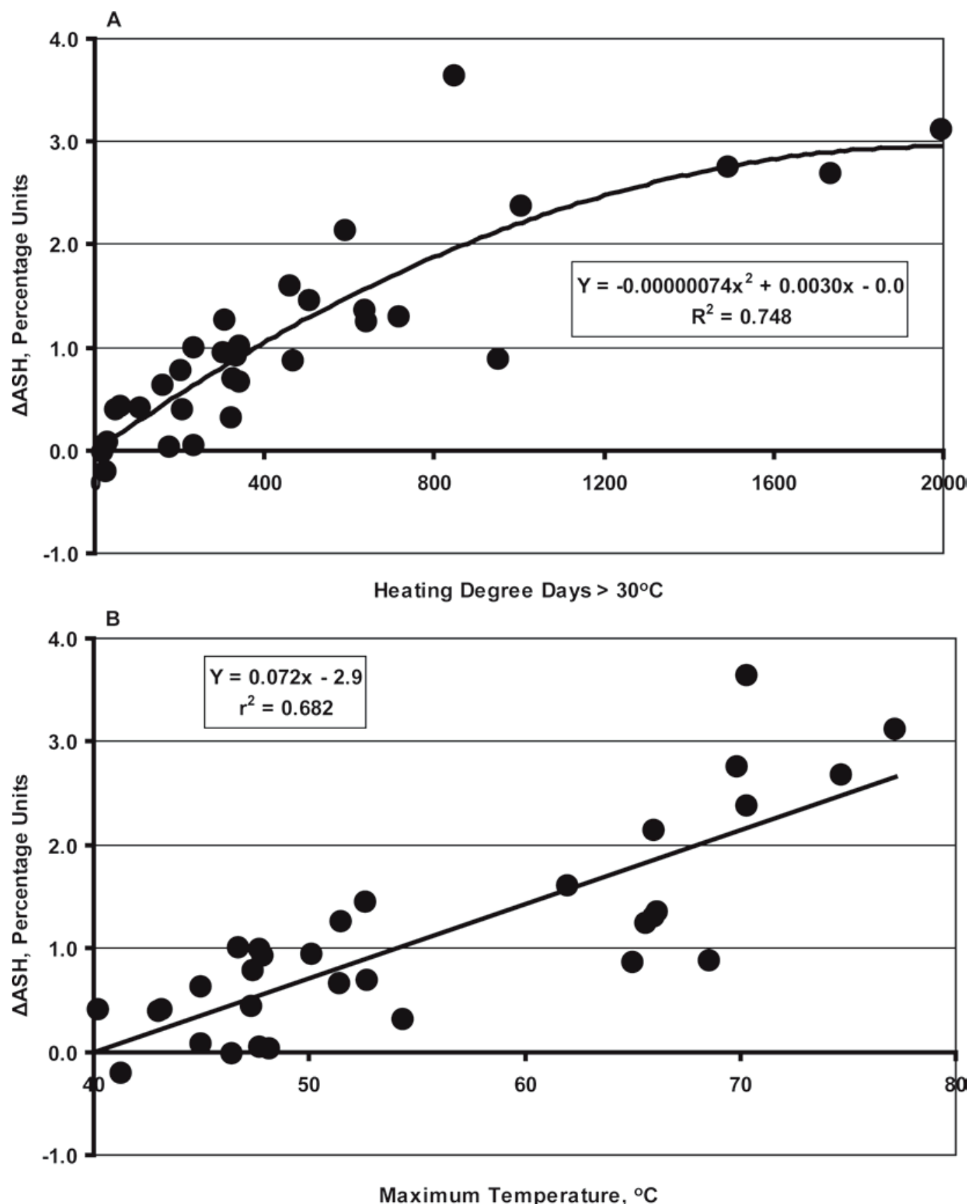

Figure 2. Changes in concentrations of whole-plant ash (poststorage - prestorage; $\Delta \mathrm{ASH})$ as affected by heating degree days $>30^{\circ} \mathrm{C}(\mathrm{A})$ and maximum internal bale temperature (B). The mean initial concentration of whole-plant ash (weighted based on the number of treatments from the high-, intermediate-, and low-moisture harvests) was $11.2 \%$, which corresponds generally to $\Delta \mathrm{ASH}=0$ on the $\mathrm{y}$-axis.

explained relatively large proportions $\left(\mathrm{R}^{2} \geq 0.682\right)$ of the variation in the data.

\section{IVTD}

Concentrations of IVTD for samples obtained before storage, and from the bale surface and core following storage are summarized in Table 4 for the LM, IM, and HM harvests. Regressions of $\triangle$ IVTD on HDD (Figure $3 \mathrm{~A}$ ) or MAX (Figure 3B) indicated that depressions in IVTD during storage are closely associated with spontaneous heating, but the most appropriate regression model varied with the specific measure of heating. For HDD, a nonlinear regression model with the 


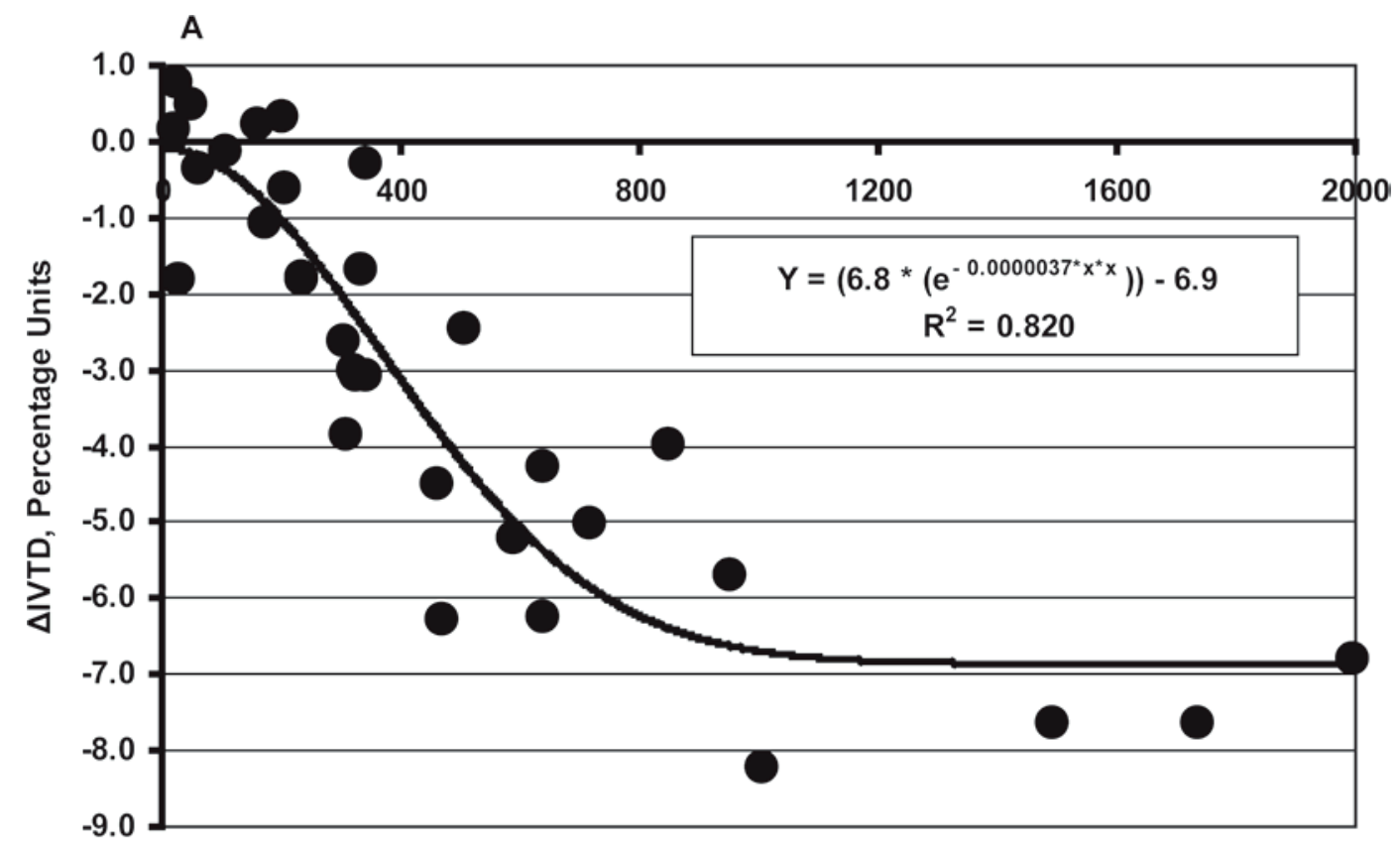

B

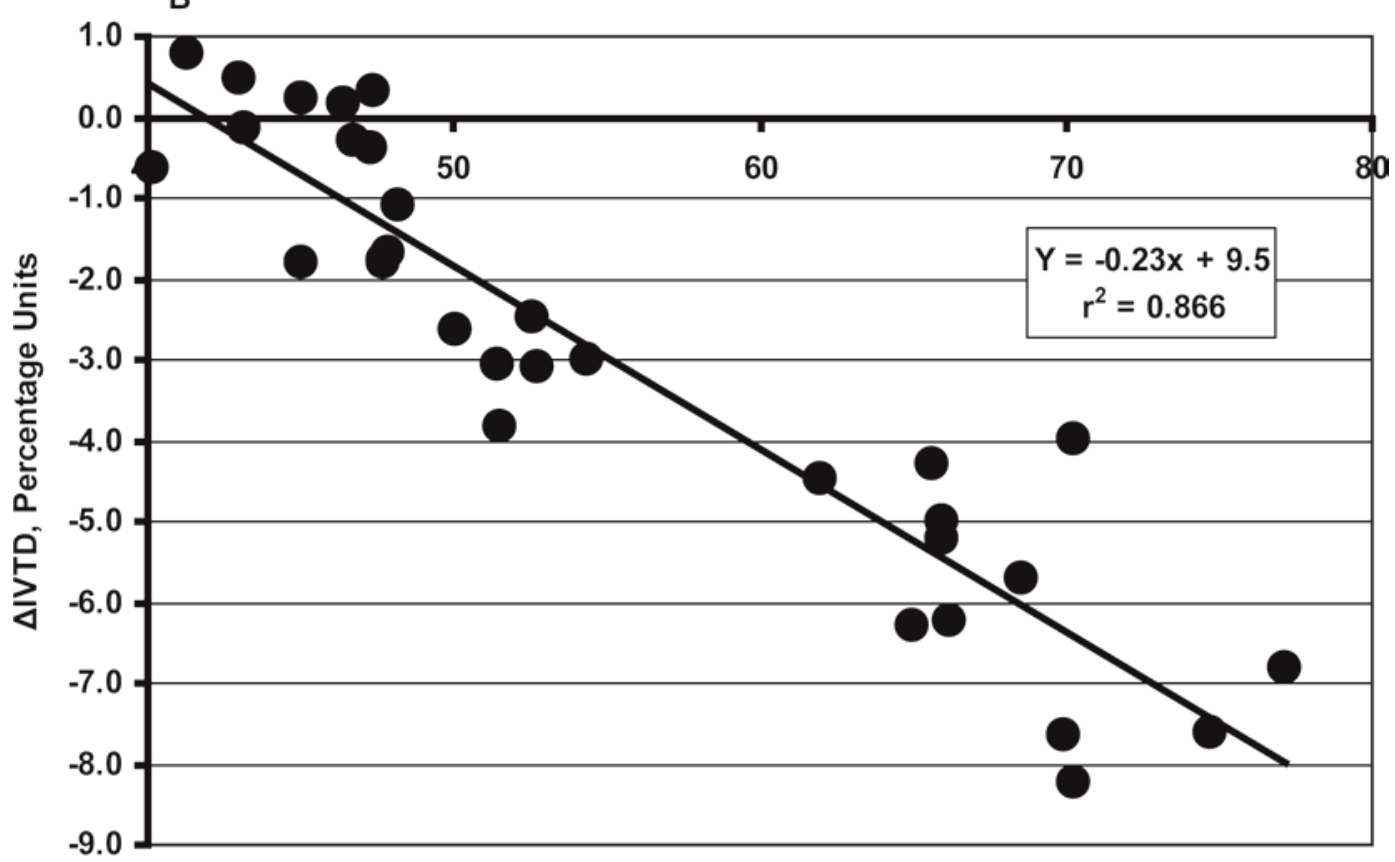

Maximum Temperature, ${ }^{\circ} \mathrm{C}$

Figure 3. Changes in concentrations of 48-h in vitro true digestibility (poststorage - prestorage; $\Delta$ IVTD) as affected by heating degree days $>30^{\circ} \mathrm{C}(\mathrm{A})$ and maximum internal bale temperature (B). The mean prestorage concentration of IVTD (weighted based on the number of treatments from the high-, intermediate-, and low-moisture harvests) was $77.2 \%$, which corresponds generally to $\Delta$ IVTD $=0$ on the $\mathrm{y}$-axis.

independent variable squared was most appropriate for explaining the relationship between $\triangle$ IVTD and HDD. For this pooled set of 32 treatment combinations, the regression curve became asymptotic at approximately -6.9 percentage units of IVTD, which is a reduction of about $9 \%$ over this extensive range of heating relative to prestorage concentrations and was characterized by a relatively high coefficient of determination $\left(\mathrm{R}^{2}=\right.$ 0.820 ). The relationship with MAX was simpler mathematically, exhibiting a linear decline as MAX increased, 
Table 5. In situ disappearance kinetics of DM for 18 bale moisture $\times$ bale diameter interactive treatments and 2 prestorage controls selected from high (HM) and intermediate (IM) moisture harvests ${ }^{1}$

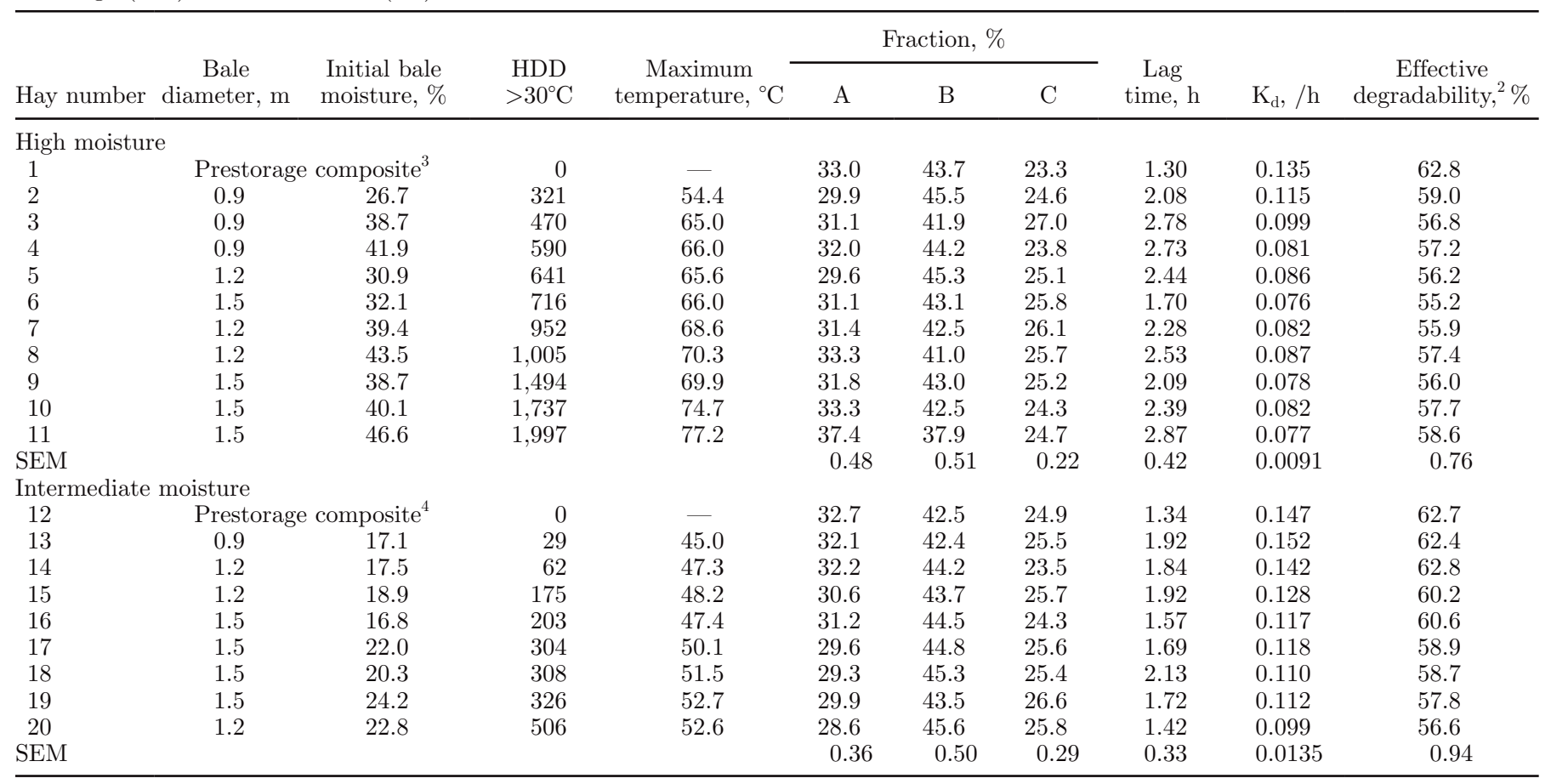

${ }^{1} \mathrm{HDD}>30^{\circ} \mathrm{C}=$ heating degree days accumulated during bale storage; fraction $\mathrm{A}=$ fraction of total DM pool disappearing at a rate too rapid to measure; fraction $\mathrm{B}=$ fraction of total $\mathrm{DM}$ pool disappearing at a measurable rate; fraction $\mathrm{C}=$ fraction of total DM pool unavailable in the rumen; and $\mathrm{K}_{\mathrm{d}}=$ fractional rate constant.

${ }^{2}$ Calculated as $\mathrm{A}+\mathrm{B} \times\left[\left(\mathrm{K}_{\mathrm{d}}+\mathrm{Kp}\right) / \mathrm{K}_{\mathrm{d}}\right]$, where $\mathrm{Kp}$ was the ruminal passage rate, which was arbitrarily set at 0.06/h (Hoffman et al., 1993).

${ }^{3}$ Composite equally weighted with sample obtained immediately after baling from hays 2 through 11 .

${ }^{4}$ Composite equally weighted with sample obtained immediately after baling from hays 13 through 20 .

and a relatively high coefficient of determination $\left(\mathrm{r}^{2}\right.$ $=0.866)$. Previously, in vitro DM disappearance was related to both MAX and HDD by simple linear regression techniques (Coblentz et al., 2000); however, those studies were conducted with small rectangular bales that did not exhibit the extremes of heating represented across the current studies.

\section{In Situ DM Disappearance Kinetics}

Fractions A, B, and C, as well as discrete lag time, $\mathrm{K}_{\mathrm{d}}$, and effective ruminal degradability are summarized in Table 5 for the 18 poststorage treatment combinations sampled from the bale core plus 2 prestorage controls from the HM and IM harvests. Although selections were made to offer the best possible coverage of the entire range of heating incurred across these hay harvests, they were weighted more heavily with HDD accumulations between 29 and $641 \mathrm{~d}$ (12 hays), which is probably the most relevant part of the overall range with respect to production-scale hay production.

Fractions $\boldsymbol{A}, \boldsymbol{B}$, and $\boldsymbol{C}$. Changes in the percentage of forage DM that disappeared from Dacron bags at a rate too fast to measure $(\Delta \mathrm{A})$ were related to HDD (Figure 4A) in a complex quartic relationship exhibiting a high coefficient of determination $\left(\mathrm{R}^{2}=0.852\right)$. Generally, differences between post- and prestorage estimates became increasingly negative over low and modest levels of heating $(<500 \mathrm{HDD})$, but then increased slowly thereafter before becoming sharply positive at extreme $(>1,500)$ accumulations of HDD. The associated regression on MAX (Figure 4B) was quadratic $\left(\mathrm{R}^{2}\right.$ $=0.839)$, but generally exhibited a similar pattern; $\Delta \mathrm{A}$ became increasingly negative at low and modest MAX, but increased thereafter, also becoming sharply positive when MAX exceeded $75^{\circ} \mathrm{C}$. Regression relationships for $\triangle \mathrm{B}$ on HDD (Figure 5A) and MAX (Figure 5B) were quartic $\left(R^{2}=0.760\right)$ and quadratic $\left(R^{2}=0.760\right)$, respectively, and essentially were mirror-opposite responses relative to $\Delta \mathrm{A}$. During storage, $\Delta \mathrm{C}$ became positive following low or modest heating, measured as either HDD (Figure 6A) or MAX (Figure 6B), before declining slightly at more extreme levels of heating. Quadratic relationships with lower $\mathrm{R}^{2}$ statistics $(0.465$ and 0.535 , respectively) were observed in both cases, but both regression curves reached their apex at $<3.0$ 
A

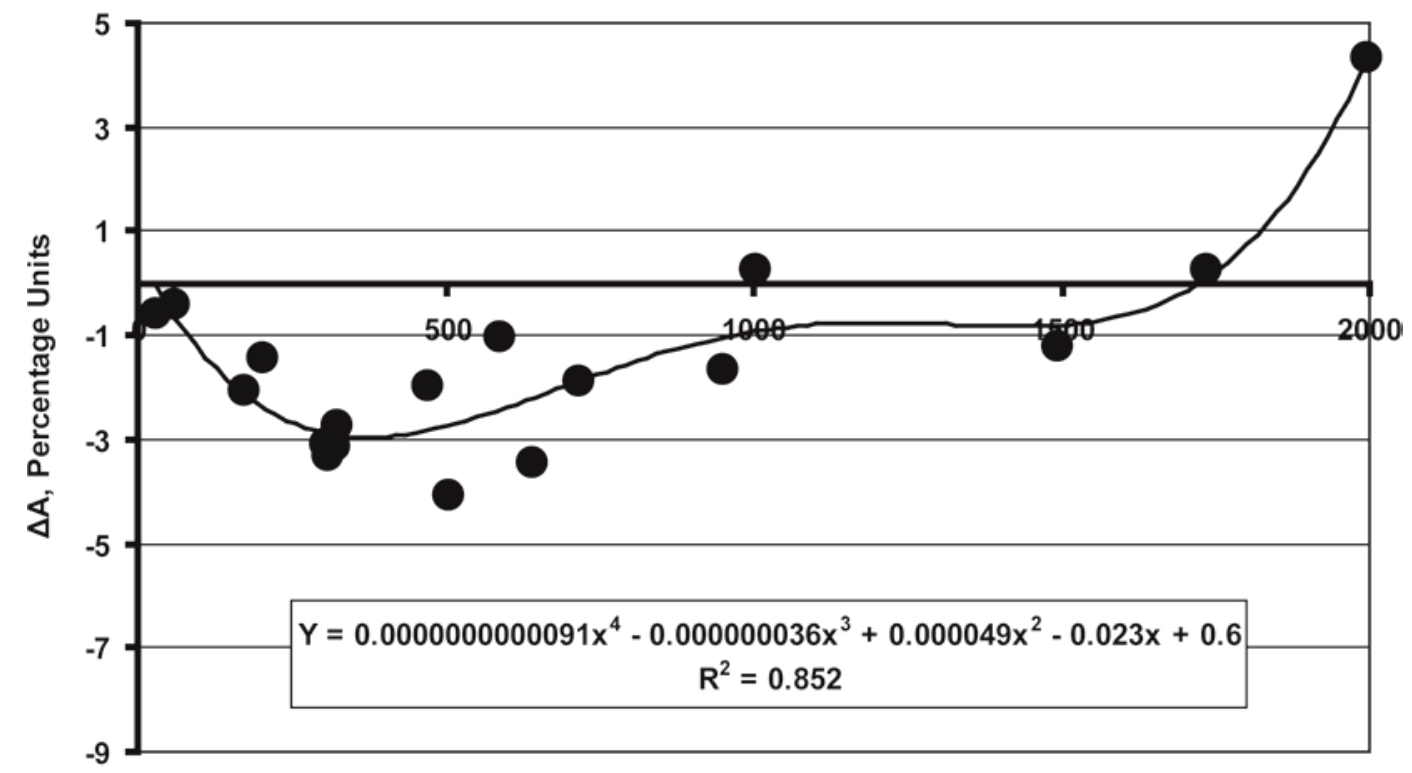

B

Heating Degree Days $>30^{\circ} \mathrm{C}$

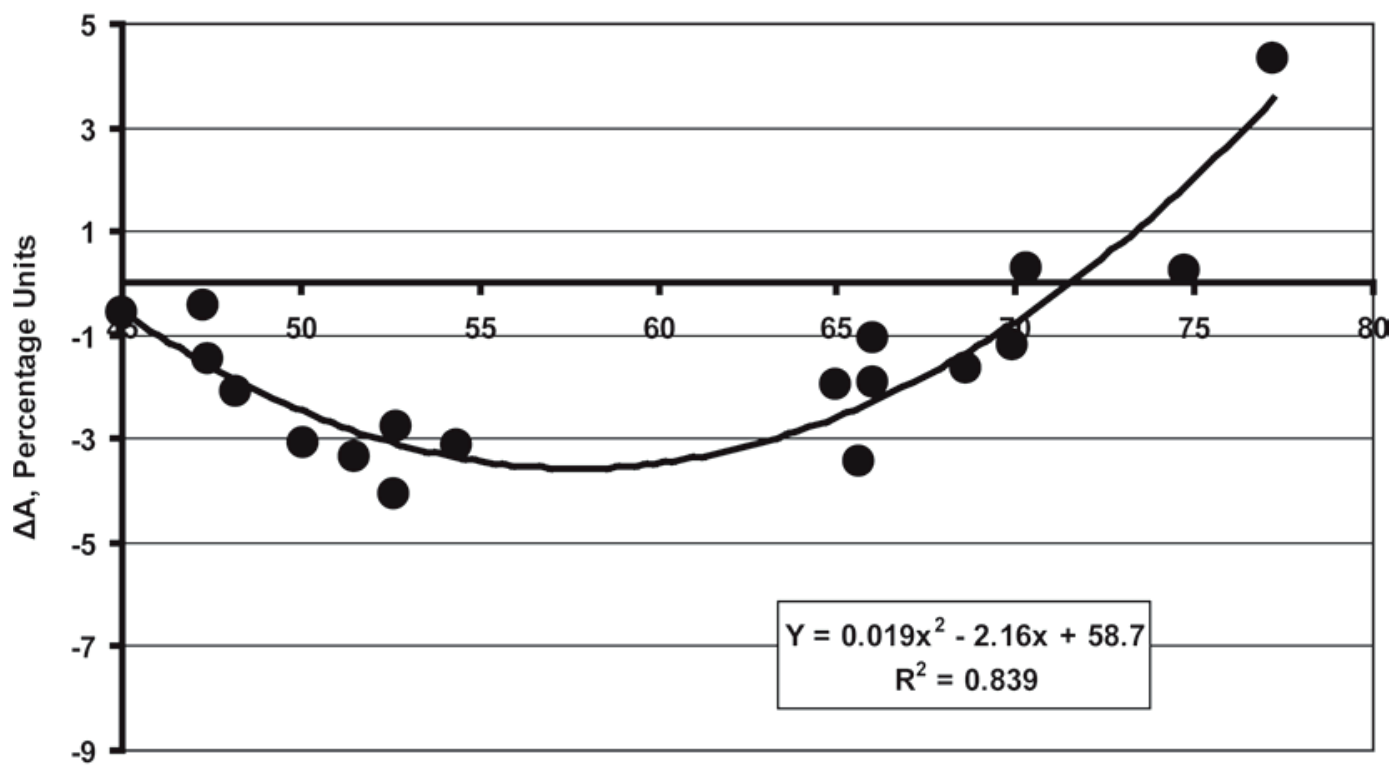

Maximum Temperature, ${ }^{\circ} \mathrm{C}$

Figure 4. Changes in percentages of $\mathrm{DM}$ disappearing from Dacron bags at a rate too rapid to measure (poststorage - prestorage; $\Delta \mathrm{A}$ ) as affected by heating degree days $>30^{\circ} \mathrm{C}(\mathrm{A})$ and maximum internal bale temperature $(\mathrm{B})$. The mean prestorage concentration of fraction $\mathrm{A}$ (weighted based on the number of treatments from the high- and intermediate-moisture harvests) was $32.9 \%$ of DM, which corresponds generally to $\Delta \mathrm{A}=0$ on the $\mathrm{y}$-axis.

percentage units of DM, thereby indicating that the overall limit of ruminal availability was reduced only minimally by spontaneous heating, regardless of the intensity of the heating response.

Taken in total, regressions of $\Delta \mathrm{A}, \Delta \mathrm{B}$, and $\Delta \mathrm{C}$ on HDD and MAX suggest that pools of DM partitioned based on susceptibility to ruminal disappearance are fluid over the wide range of spontaneous heating. Based on the somewhat limited responses exhibited by $\Delta \mathrm{C}$, it appears that this fluidity was mostly limited to the movement of DM pools between fractions A and B. Declining percentages of total DM within fraction A and concomitant increases in fraction B have been associated with spontaneous heating in another study with 


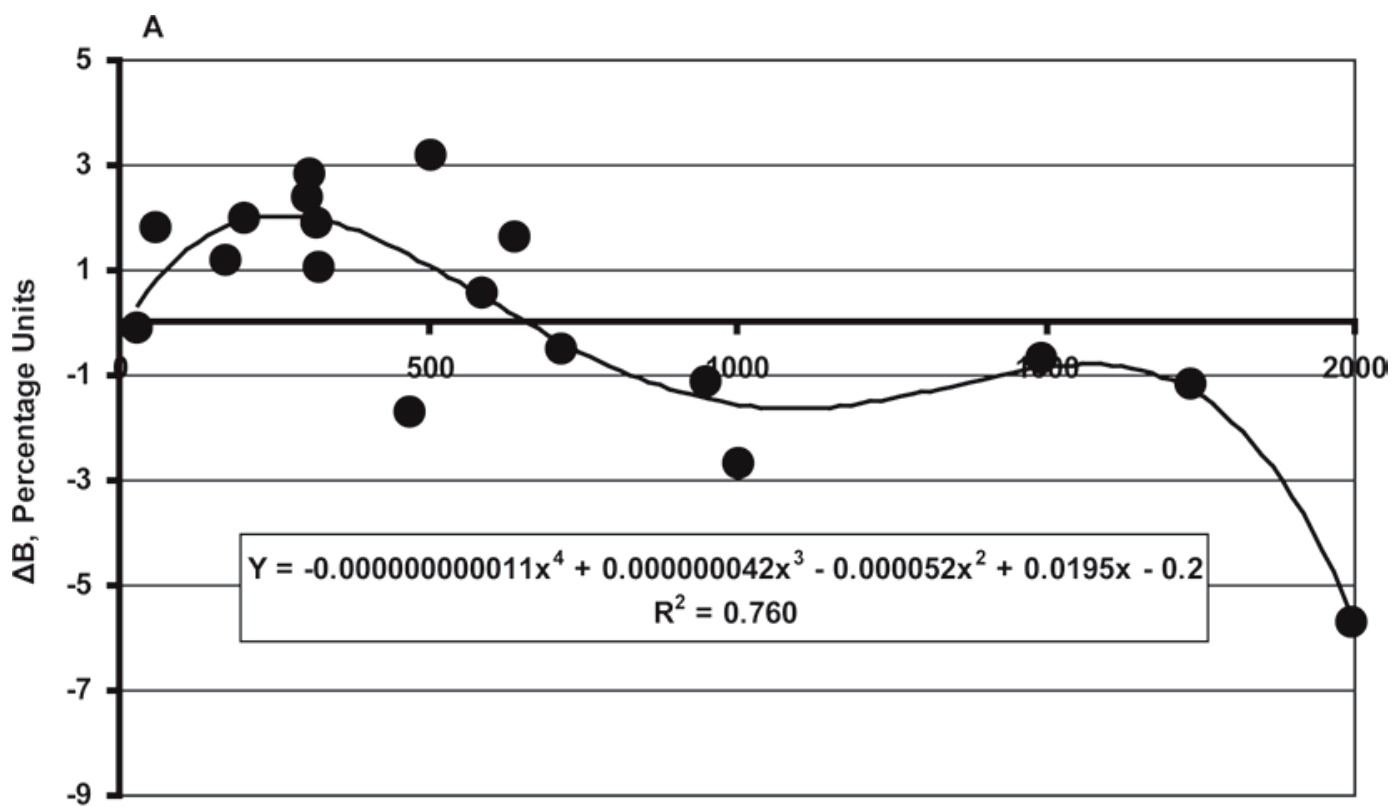

Heating Degree Days $>30^{\circ} \mathrm{C}$

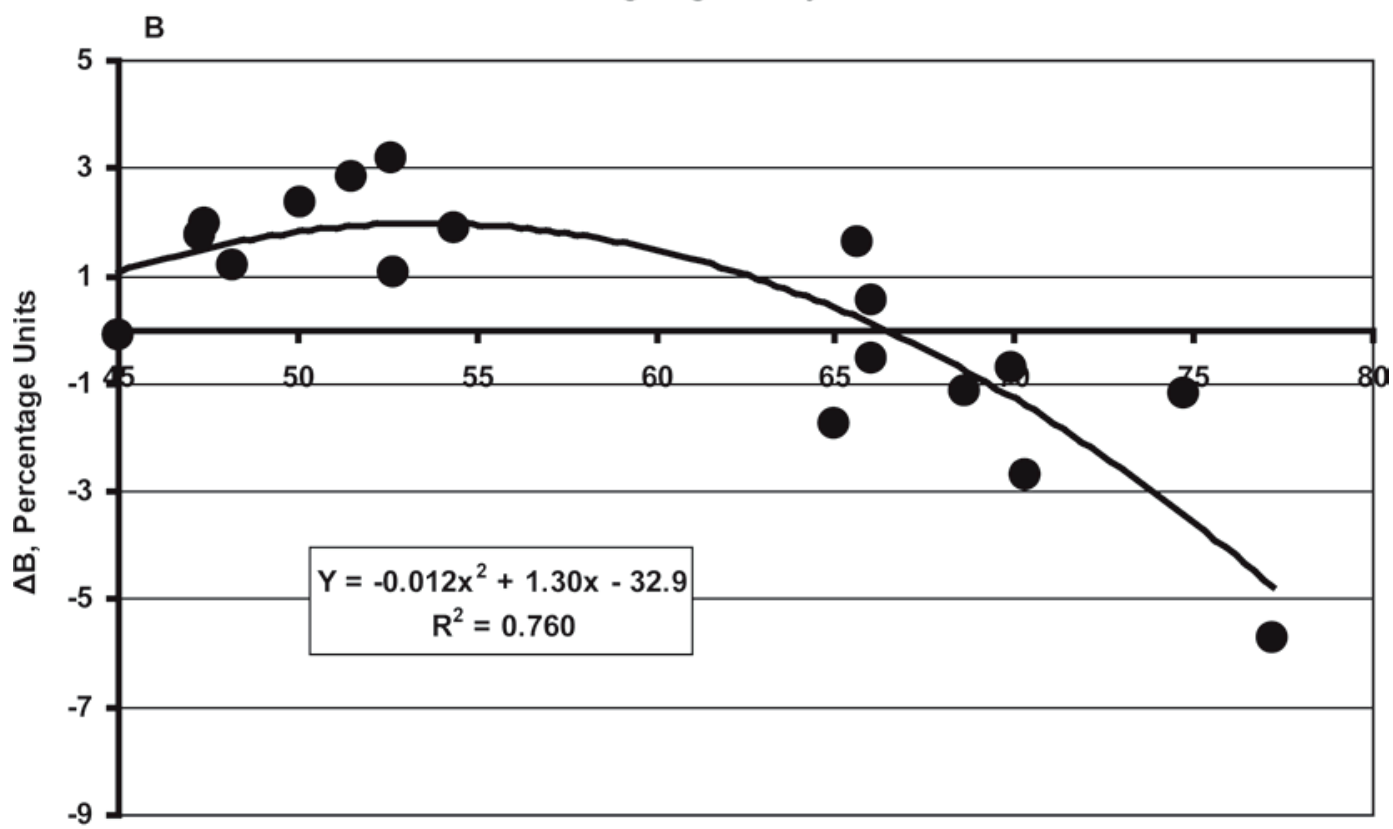

Maximum Temperature, ${ }^{\circ} \mathrm{C}$

Figure 5. Changes in percentages of DM disappearing from Dacron bags at a measurable rate (poststorage - prestorage; $\Delta \mathrm{B}$ ) as affected by heating degree days $>30^{\circ} \mathrm{C}(\mathrm{A})$ and maximum internal bale temperature (B). The mean prestorage concentration of fraction $\mathrm{B}$ (weighted based on the number of treatments from the high- and intermediate-moisture harvests) was $43.2 \%$ of $\mathrm{DM}$, which corresponds generally to $\Delta \mathrm{B}$ $=0$ on the y-axis.

bermudagrass hays (McBeth et al., 2003), but that work was conducted using small rectangular bales that accumulated a maximum of $401 \mathrm{HDD}$ based on a $35^{\circ} \mathrm{C}$ threshold. However, those responses are consistent with our observations over a low to modest ( $<500$ HDD) range of spontaneous heating. Beyond this heating range, the increasing values observed for $\Delta \mathrm{A}$ were un- expected and are more difficult to explain. Considering the statistical procedures used for these kinetic calculations, fraction A cannot be equated directly with water solubility; however, fraction A represents a pool of DM that was not recovered following machine rinsing, and therefore moves from the bag in association with water. Potentially, this could occur with water serving 


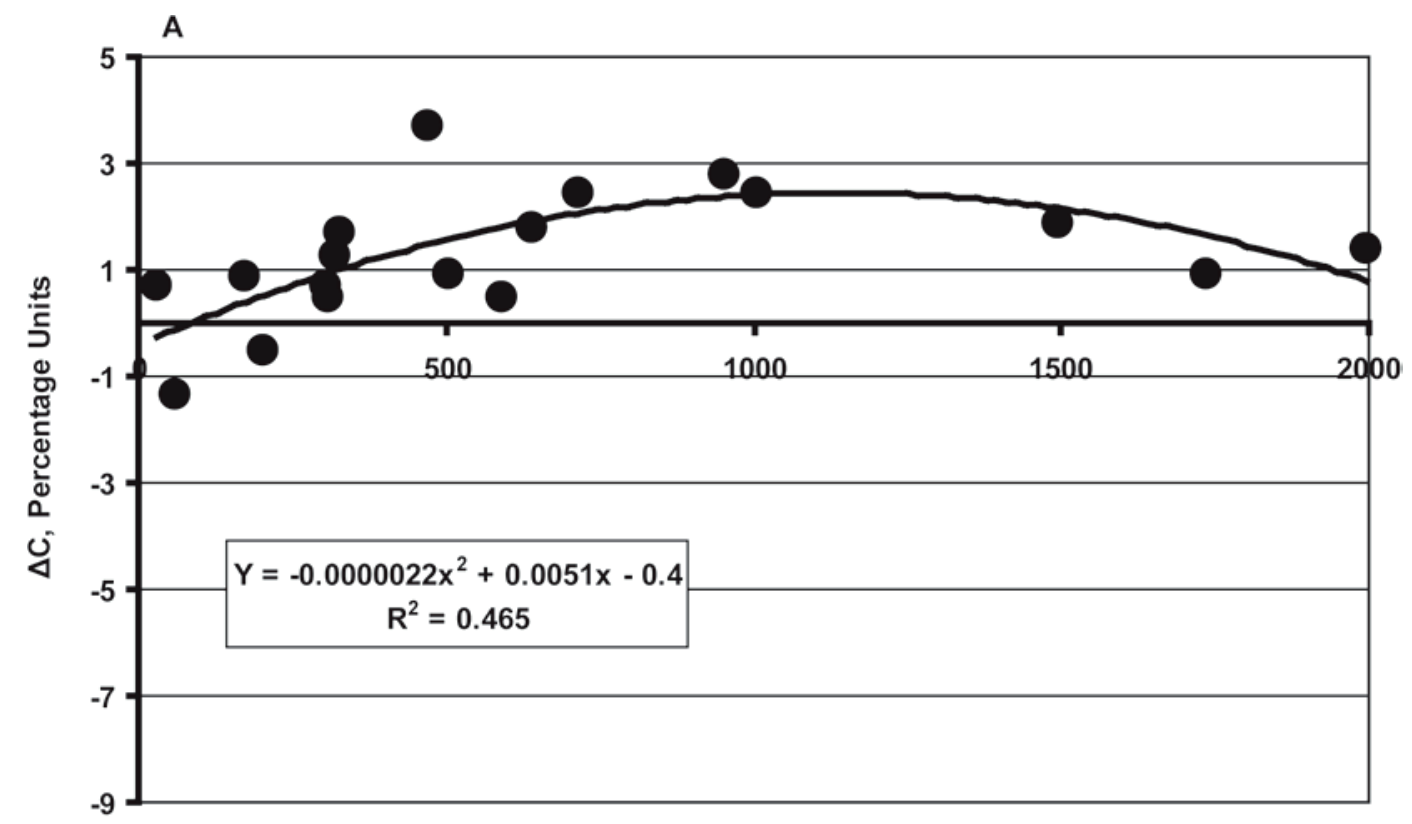

Heating Degree Days $>30^{\circ} \mathrm{C}$

B

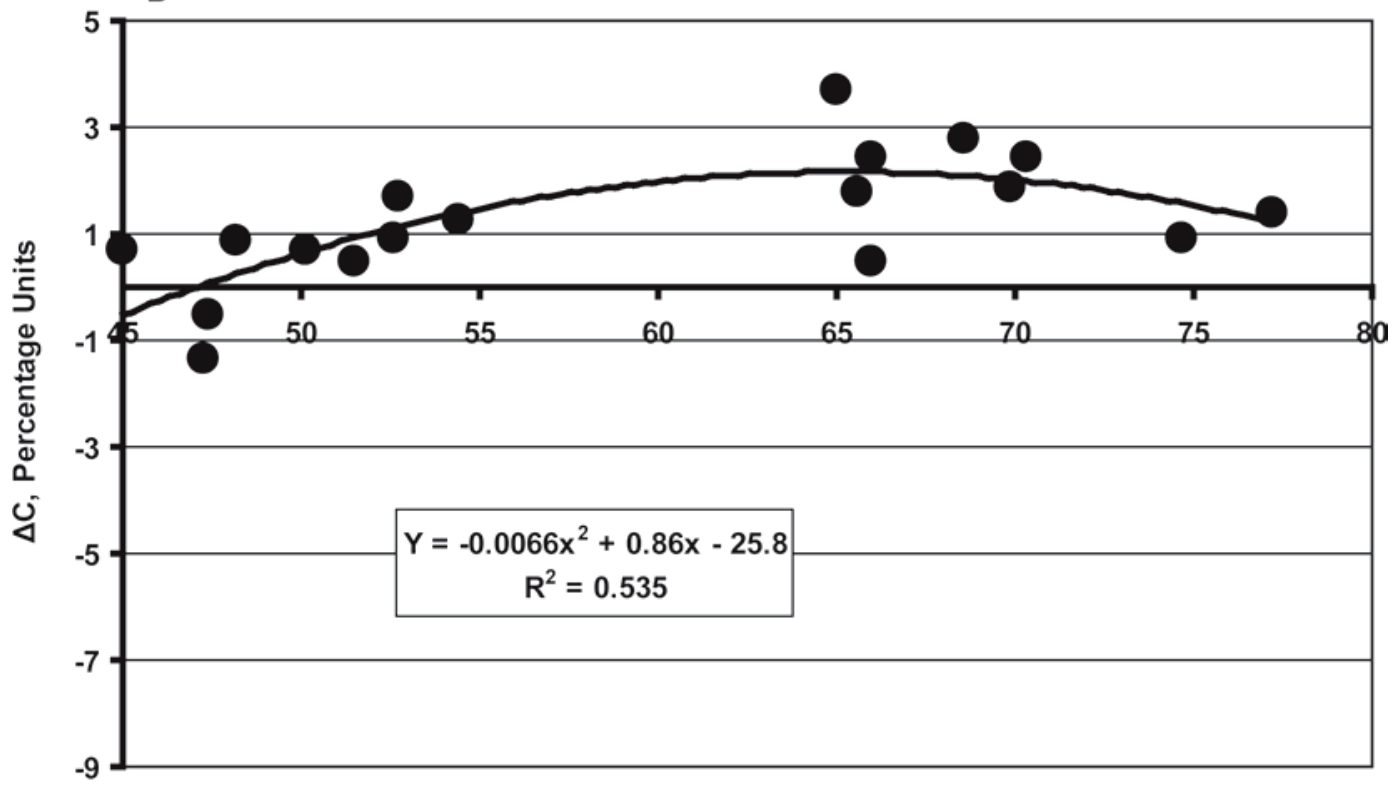

Maximum Temperature, ${ }^{\circ} \mathrm{C}$

Figure 6. Changes in percentages of DM unavailable in the rumen (poststorage - prestorage; $\Delta \mathrm{C}$ ) as affected by heating degree days $>30^{\circ} \mathrm{C}$ (A) and maximum internal bale temperature (B). The mean prestorage concentration of fraction $\mathrm{C}$ (weighted based on the number of treatments from the high- and intermediate-moisture harvests) was $24.0 \%$ of $\mathrm{DM}$, which corresponds generally to $\Delta \mathrm{C}=0$ on the $\mathrm{y}$-axis.

as a solvent or as a physical carrier of small particles. Relative to unheated forages, a greater percentage of the total DM within heated forages may originate from various forms of microbial debris, such as dust, mold spores, and so on. In addition, bales that incurred the most extreme heating exhibited large pockets of charred, blackened forage within the bale core. Charring could potentially affect the physical characteristics of the forage, such as brittleness, and the subsequent distribution of particle size after grinding. One or both of these factors may have increased the proportion of ground forage particles that were small enough to be forced physically from the Dacron bags during machine rinsing, thereby increasing estimates of $\Delta \mathrm{A}$.

Lag Time. Relationships between $\triangle \mathrm{LAG}$ and HDD (Figure 7A) or MAX (Figure 7B) were best explained 

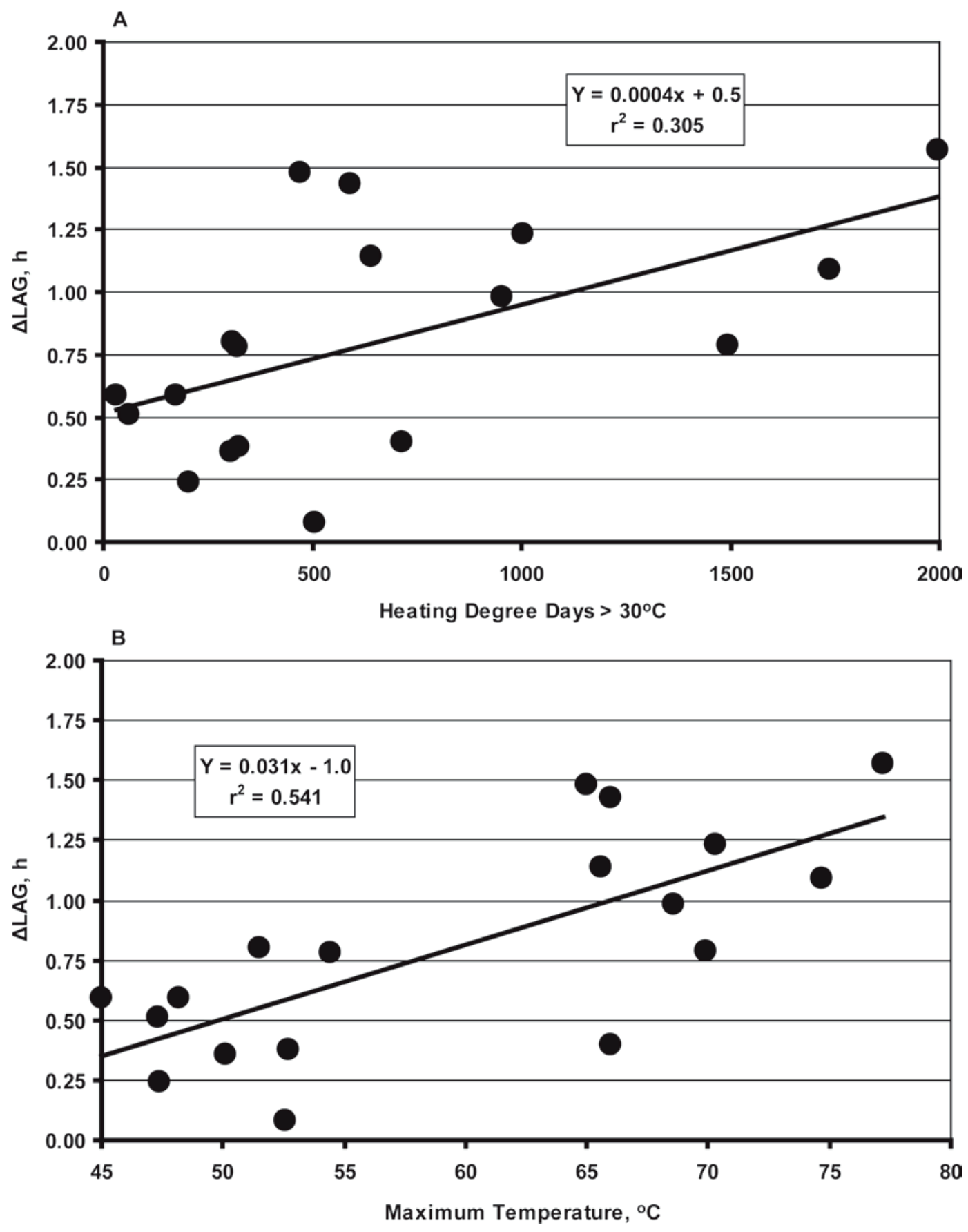

Figure 7. Changes in lag time (poststorage - prestorage; $\Delta$ LAG) as affected by heating degree days $>30^{\circ} \mathrm{C}(\mathrm{A})$ and maximum internal bale temperature (B). The mean prestorage lag time (weighted based on the number of treatments from the high- and intermediate-moisture harvests) was $1.32 \mathrm{~h}$, which corresponds generally to $\Delta \mathrm{LAG}=0$ on the y-axis.

with a simple linear model, but coefficients of determination were relatively poor $\left(\mathrm{r}^{2}=0.305\right.$ and 0.541 , respectively). In both cases, $\triangle \mathrm{LAG}$ increased with heating, thereby indicating that the time delay associated with initiation of DM disappearance from fraction B increased as hays incurred more heating during storage. Previously, McBeth et al. (2003) reported no relation- ship between lag time and HDD for small rectangular bales of bermudagrass that heated spontaneously during storage.

Disappearance Rate. Rates of ruminal DM disappearance for unheated control hays obtained from HM and IM harvests ( 0.135 and $0.147 / \mathrm{h}$, respectively; Table 5) were consistent with other research reports. 
A

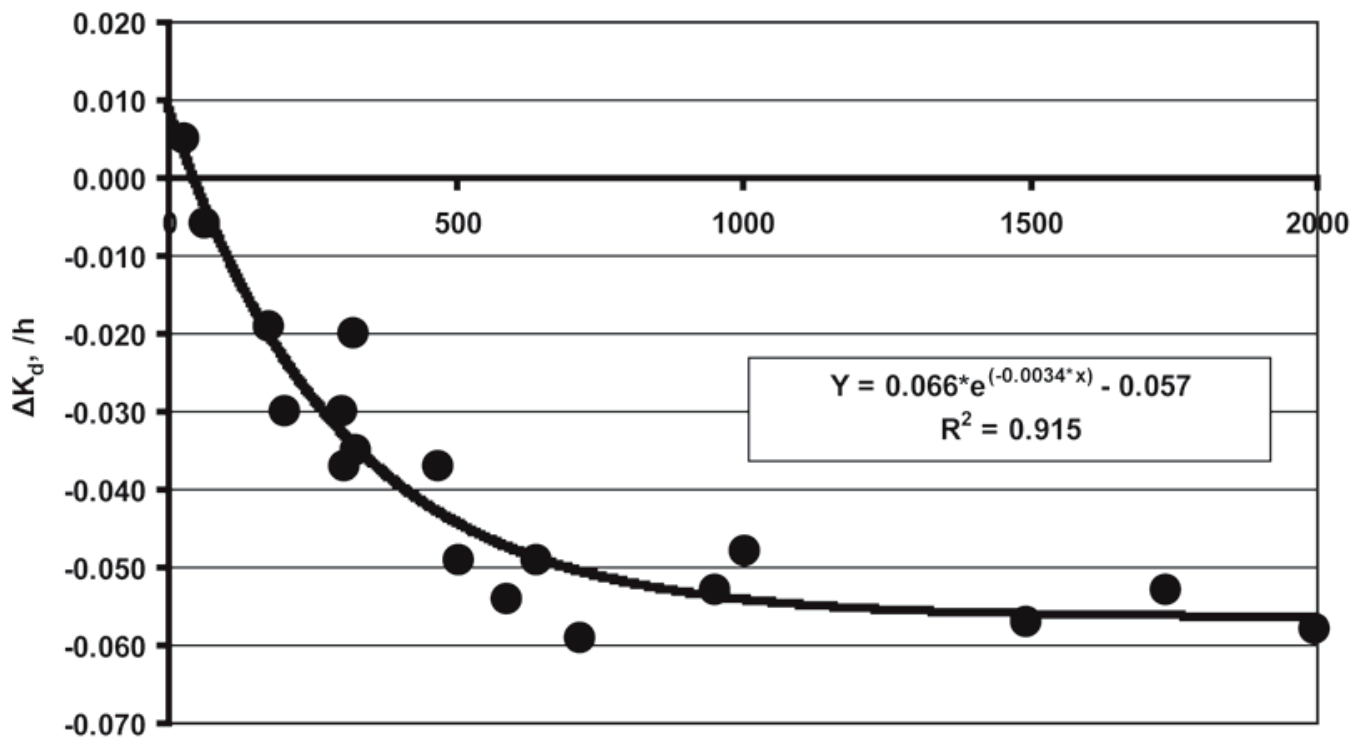

B

Heating Degree Days $>30^{\circ} \mathrm{C}$

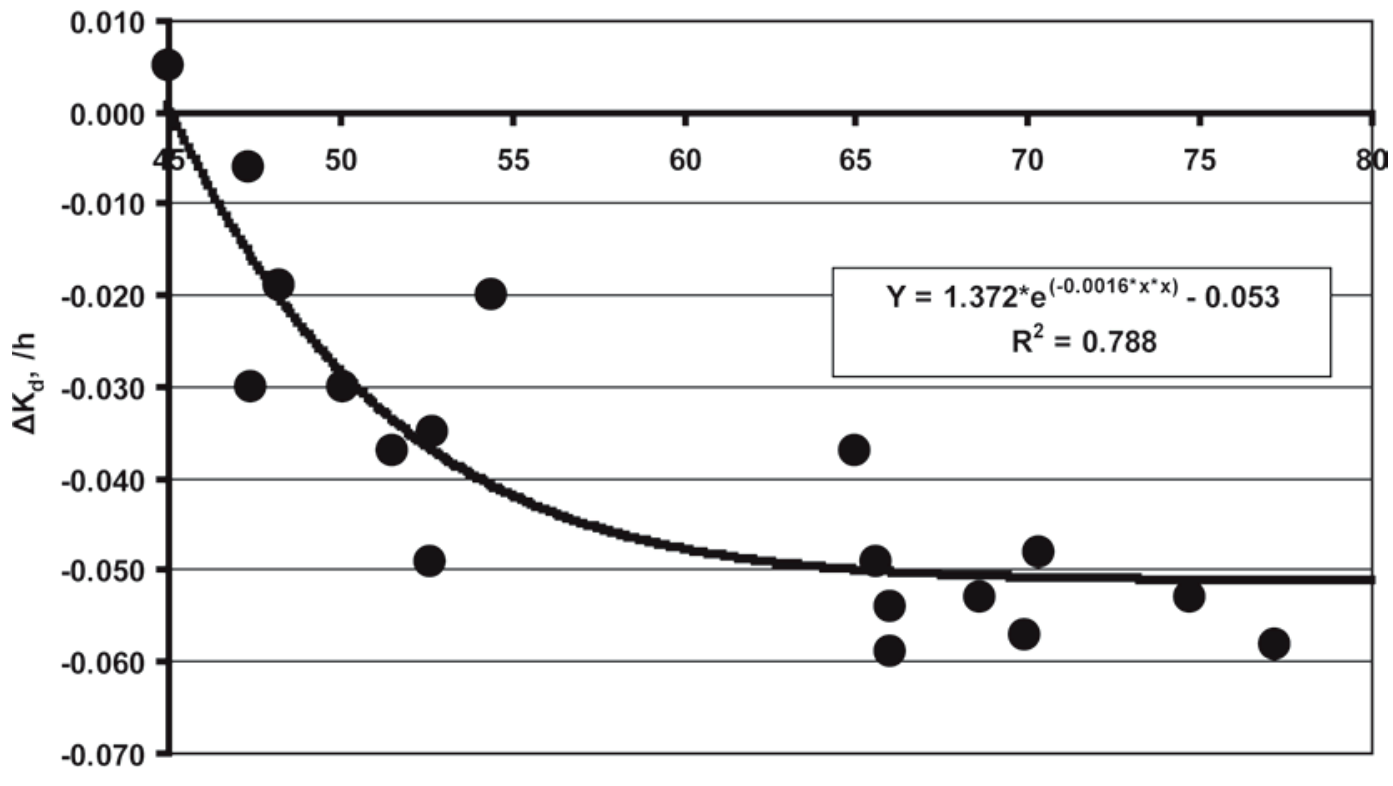

Maximum Temperature, ${ }^{\circ} \mathrm{C}$

Figure 8. Changes for in situ disappearance rates of DM (poststorage - prestorage; $\Delta \mathrm{K}_{\mathrm{d}}$ ) as affected by heating degree days $>30^{\circ} \mathrm{C}(\mathrm{A})$ and maximum internal bale temperature $(\mathrm{B})$. The mean prestorage $\mathrm{K}_{\mathrm{d}}$ (weighted based on the number of treatments selected from the high- and intermediate-moisture harvests) was $0.140 / \mathrm{h}$, which corresponds generally to $\Delta \mathrm{K}_{\mathrm{d}}=0$ on the $\mathrm{y}$-axis.

Hoffman et al. (1993) reported estimates of $\mathrm{K}_{\mathrm{d}}$ for alfalfa harvested at the late-vegetative, late-bud, and midbloom stages of growth in central Wisconsin to be $0.15,0.16$, and $0.13 / \mathrm{h}$, respectively. Similarly, Ogden et al. (2005) reported a $0.143 / \mathrm{h}$ estimate of $\mathrm{K}_{\mathrm{d}}$ for unheated alfalfa hay stored in small rectangular bales in Arkansas. Previously, McBeth et al. (2003) reported that $K_{d}$ for disappearance of DM slowed significantly with spontaneous heating in bermudagrass hays, and this pattern also was observed in the present study. Regressions of $\Delta \mathrm{K}_{\mathrm{d}}$ on HDD (Figure $8 \mathrm{~A}$ ) and MAX (Figure $8 \mathrm{~B}$ ) indicate that $\Delta \mathrm{K}_{\mathrm{d}}$ became rapidly negative until measures of spontaneous heating approached $\sim 1,000 \mathrm{HDD}$ or a MAX of $\sim 60^{\circ} \mathrm{C}$, but then became asymptotic with more extreme heating. These responses were best fit by nonlinear regression models; however, 

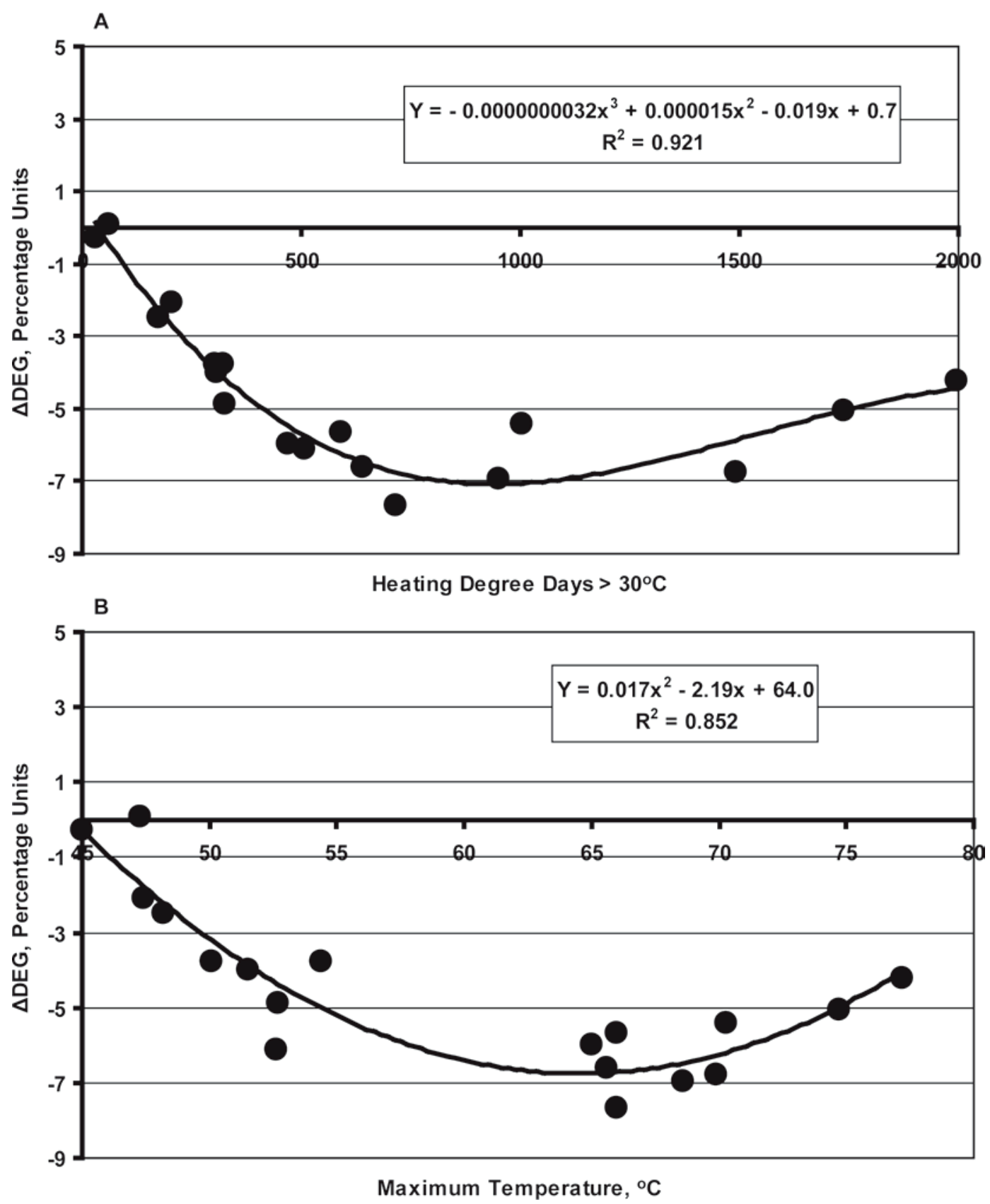

Figure 9. Changes in effective ruminal disappearance of DM (poststorage - prestorage; $\Delta \mathrm{DEG}$ ) as affected by heating degree days $>30^{\circ} \mathrm{C}$ (A) and maximum internal bale temperature (B). The mean prestorage effective ruminal disappearance of DM (weighted based on the number of treatments from the high- and intermediate-moisture harvests) was $62.8 \%$, which corresponds generally to $\Delta \mathrm{DEG}=0$ on the y-axis. Effective degradability was calculated based on a $0.060 / \mathrm{h}$ ruminal passage rate.

the smallest residuals were obtained by squaring MAX $\left(\mathrm{R}^{2}=0.788\right)$, but not $\operatorname{HDD}\left(\mathrm{R}^{2}=0.915\right)$. Overall, these data suggest a very close association between $\mathrm{K}_{\mathrm{d}}$ and spontaneous heating. The substantially improved fit associated with regression on HDD compared with MAX suggests that heating effects on $K_{d}$, are, at least in part, cumulative over the entire storage period rather than driven entirely by the most intense period of heating within the bale.

Effective Ruminal Degradability. The effective ruminal degradability of DM for unheated control hays produced from HM and IM harvests (62.8 and $62.7 \%$, respectively; Table 5) were within the range of 73.4 to $55.2 \%$ established by Hoffman et al. (1993) for alfalfa 
hays harvested at late-vegetative, late-bud, and midbloom stages of growth, and calculated at a comparable $0.06 / \mathrm{h}$ particulate passage rate. Regressions of $\triangle \mathrm{DEG}$ on HDD (Figure 9A) and MAX (Figure 9B) illustrated an increasingly negative $\triangle \mathrm{DEG}$ over low-to-moderate spontaneous heating that closely resembled the response described previously for $\Delta \mathrm{K}_{\mathrm{d}}$. Unlike the response for $\Delta \mathrm{K}_{\mathrm{d}}, \Delta \mathrm{DEG}$ increased slightly at extreme levels of spontaneous heating, thereby resulting in selection of cubic $\left(\mathrm{R}^{2}=0.921\right)$ and quadratic $\left(\mathrm{R}^{2}=0.852\right)$ regression models for HDD and MAX, respectively. The most logical explanation for increases in $\triangle \mathrm{DEG}$ at extreme levels of both HDD and MAX is that concurrent increases in $\Delta \mathrm{A}$ over these same ranges of heating made measurable contributions to the ruminally degradable pool of DM. Because fraction A disappears at a rate too rapid to measure and is not included in calculations of $K_{d}$, this also would explain why responses for $\Delta K_{d}$ were asymptotic at the most extreme levels of heating. Overall, these polynomial regressions suggest that the effective ruminal degradability of DM is reduced in a close relationship with spontaneous heating, thereby supporting results from previous in situ (McBeth et al., 2003) and in vivo (Montgomery et al., 1986; McBeth et al., 2001) research efforts. However, it remains unclear whether these depressions in effective ruminal degradability are strictly the result of respiratory losses of highly digestible forms of DM during storage, or whether they are related to changes in the composition and degradability of fiber, or a combination of both.

\section{CONCLUSIONS}

Spontaneous heating in hay has long been associated with microbial respiration of plant sugars, as well as DM loss and depressed digestibility. In these studies, both bale moisture and diameter had positive effects on temperature development within 96 large-round bales. Measures of spontaneous heating are excellent predictor variables for DM recovery within large-round bales following storage, as well as changes in IVTD, $\mathrm{K}_{\mathrm{d}}$, and effective ruminal degradability that occur during the storage period. Ruminal disappearance rate and measures of digestibility generally declined rapidly until measures of heating reached approximately 1,000 HDD or a $60^{\circ} \mathrm{C} \mathrm{MAX}$; after that point, further depressions in $\mathrm{K}_{\mathrm{d}}$, IVTD, or effective ruminal disappearance were limited. It remains unresolved whether depressions in IVTD and effective ruminal disappearance are strictly the result of respiratory losses during storage of highly digestible forms of DM, such as sugars, or whether they are related to changes in the composition and degradability of fiber, or a combination of both mechanisms.

\section{REFERENCES}

Coblentz, W. K., J. O. Fritz, K. K. Bolsen, and R. C. Cochran. 1996. Quality changes in alfalfa hay during storage in bales. J. Dairy Sci. 79:873-885.

Coblentz, W. K., J. O. Fritz, K. K. Bolsen, R. C. Cochran, and L. Fu. 1997a. Relating sugar fluxes over time to quality changes in alfalfa hay. Agron. J. 88:800-806.

Coblentz, W. K., J. O. Fritz, R. C. Cochran, W. L. Rooney, and K. K. Bolsen. 1997b. Protein degradation responses to spontaneous heating in alfalfa hay evaluated by in situ and ficin methods. J. Dairy Sci. 80:700-713.

Coblentz, W. K., J. E. Turner, D. A. Scarbrough, K. E. Lesmeister Z. B. Johnson, D. W. Kellogg, K. P. Coffey, L. J. McBeth, and J. S. Weyers. 2000. Storage characteristics and quality changes in bermudagrass hay as affected by moisture content and density of rectangular bales. Crop Sci. 40:1375-1383.

Collins, M. 1995. Hay preservation effects on yield and quality. Pages 67-90 in Post-Harvest Physiology and Preservation of Forages. CSSA Special Publication No. 22. K. J. Moore and M. A. Peterson, ed. Am. Soc. Agron., Crop Sci. Soc. Am., and Soil Sci. Soc. Am., Madison WI.

Collins, M., W. H. Paulson, M. F. Finner, N. A. Jorgensen, and C. R. Keuler. 1987. Moisture and storage effects on dry matter and quality losses of alfalfa in round bales. Trans. ASAE 30:913917.

Goering, H. K., and P. J. Van Soest. 1970. Pages 8-11 in Forage Fiber Analyses (Apparatus, Reagents, Procedures, and Some Applications). Agric. Handbook No. 379. USDA-ARS, Washington, DC.

Hoffman, P. C., S. J. Sievert, R. D. Shaver, D. A. Welch, and D. K. Combs. 1993. In situ dry matter, protein, and fiber degradation of perennial forages. J. Dairy Sci. 76:2632-2643.

McBeth, L. J., K. P. Coffey, W. K. Coblentz, D. H. Hellwig, J. E. Turner, and D. A. Scarbrough. 2003. Impact of heating-degreeday accumulation during storage of bermudagrass hay on in situ degradation kinetics from steers. Anim. Feed Sci. Technol. 108:147-158.

McBeth, L. J., K. P. Coffey, W. K. Coblentz, J. E. Turner, D. A. Scarbrough, C. R. Bailey, and M. R. Stivarius. 2001. Impact of heating degree-day accumulation during bermudagrass hay storage on nutrient utilization by lambs. J. Anim. Sci. 79:2698-2703.

Mertens, D. R. 1992. Critical conditions in determining detergent fibers. Page C-1 in Proc. Natl. Forage Testing Assoc. Forage Anal. Workshop, Denver, CO. Natl. Forage Testing Assoc., Omaha, NE.

Mertens, D. R., and J. R. Loften. 1980. The effect of starch on forage fiber digestion kinetics in vitro. J. Dairy Sci. 63:1437-1446.

Montgomery, M. J., A. Tineo, B. L. Bledsoe, and H. D. Baxter. 1986. Effect of moisture content at baling on nutritive value of alfalfa orchardgrass hay in conventional and large round bales. J. Dairy Sci. 69:1847-1853.

NOAA (National Oceanic and Atmospheric Administration). 2006. Climatological data annual summary Wisconsin. Vol. 111. No. 13. National Climatic Data Center, NESDIS, NOAA, Asheville, NC.

NOAA (National Oceanic and Atmospheric Administration). 2007. Climatological data annual summary Wisconsin. Vol. 112. No. 13. National Climatic Data Center, NESDIS, NOAA, Asheville, NC.

NRC. 2001. Nutrient Requirements of Dairy Cattle. 7th rev. ed. National Academy Press, Washington, DC.

Ogden, R. K., W. K. Coblentz, K. P. Coffey, J. E. Turner, D. A. Scarbrough, J. A. Jennings, and M. D. Richardson. 2005. Ruminal in situ disappearance kinetics of dry matter and fiber in growing steers for common crabgrass sampled on seven dates in northern Arkansas. J. Anim. Sci. 83:1142-1152.

Ørskov, E. R., and I. McDonald. 1979. The estimation of protein degradability in the rumen from incubation measurements weighted according to rate of passage. J. Agric. Sci. (Camb.) 92:499-503.

Roberts, C. A. 1995. Microbiology of stored forages. Pages $21-38$ in CSSA Special Publication No. 22. K.J. Moore and M.A. Peterson, 
ed. Am. Soc. Agron., Crop Sci. Soc. Am., and Soil Sci. Soc. Am., Madison, WI.

Rotz, C. A., and R. E. Muck. 1994. Changes in forage quality during harvest and storage. Pages 828-868 in Forage quality, evaluation, and utilization. Proc. Natl. Conf. on Forage Quality, Evaluation, and Utilization, Lincoln, NE. Am. Soc. Agron., Crop Sci. Soc. Am., and Soil Sci. Soc. Am., Madison, WI.

SAS Institute. 1990. SAS/STAT: User's Guide. Version 6, 4th ed. SAS Inst., Cary, NC.

Turner, J. E., W. K. Coblentz, K. P. Coffey, R. T. Rhein, B. C. McGinley, N. W. Galdámez-Cabrerra, C. F. Rosenkrans Jr., Z B. Johnson, D. W. Kellogg, and J. V. Skinner Jr. 2004. Effects of natural rainfall and spontaneous heating on voluntary intake, digestibility, in situ disappearance kinetics, passage kinetics, and ruminal fermentation characteristics of tall fescue hay. Anim. Feed Sci. Technol. 116:15-33.
Turner, J. E., W. K. Coblentz, D. A. Scarbrough, K. P. Coffey, D. W. Kellogg, L. J. McBeth, and R. T. Rhein. 2002. Changes in nutritive value of bermudagrass hay during storage. Agron. J. 94:109-117.

Vanzant, E. S., R. C. Cochran, and E. C. Titgemeyer. 1998. Standardization of in situ techniques for ruminant feedstuff evaluation. J. Anim. Sci. 76:2717-2729.

Vanzant, E. S., R. C. Cochran, E. C. Titgemeyer, S. D. Stafford, K. C. Olsen, D. E. Johnson, and G. St. Jean. 1996. In vivo and in situ measurements of forage protein degradation in cattle. J. Anim. Sci. 74:2773-2784.

Weiss, W. P., H. R. Conrad, and N. R. S. Pierre. 1992. A theoreticallybased model for predicting total digestible nutrient values of forages and concentrates. Anim. Feed Sci. Technol. 39:95-110. 